\title{
B-cell differentiation is pressuromodulated as determined by pressuromodulation mapping: Part I, cell differentiation
}

Hemant Sarin

\begin{abstract}
Background: The episodic sub-episode block sums split-integrated weighted average-averaged gene overexpression tropy quotient (esebssiwaago $T_{\mathrm{Q}}$ ) is a measure of the $5^{\prime} \rightarrow 3^{\prime}$ reading direction intergene distance tropy that needs to be overcome for horizontal alignment of a gene for maximal transcription; and it is also an arbitrary unit measure of the intracellular pressure needed for maximal gene expression.

In this study, B-cell differentiation is studied by esebssiwaago $T_{\mathrm{Q}}$-based pressuromodulation mapping of B-cell stage marker genes.
\end{abstract}

Methods: Locations of 25 B-cell differentiation stage genes, and locations of downstream and upstream genes were mined at GeneCards and at LNCipedia, pseudogenes included and enhancers excluded. The esebssiwaago $T_{\mathrm{Q}} \mathrm{S}$ for each gene were determined. A pressuromodulation map was generated by arranging overexpressed B-cell stage marker genes in descending and ascending order by esebssiwaago $T_{Q}$ in reference to periods of B-cell polarization.

Results: The gene esebssiwaagot ${ }_{\mathrm{Q}} \mathrm{S}$ are CD34 0.65 (0.648), PRDM1 0.36 (0.356), PTPRC 0.35 (0.345), MK167 0.33 (0.329), ENPP1 0.31 (0.308), RAG2 0.31 (0.306), MS4A1 0.30 (0.299), PCNA 0.28 (0.285), ESPL1 0.28 (0.275), CD79B 0.27 (0.271), AICDA 0.27 (0.266), CD40 $0.26(0.257), A P O B E C 3 A /-B 0.22(0.216), C D 380.21(0.212), C D 270.19(0.194), A P O B E C 3 C /-D /-F /-G 0.17$ (0.173), CD19 0.15 (0.153), RAG1 0.14 (0.139), CD79A 0.14 (0.137), CR2 0.11 (0.109), and APOBEC3H 0.10 (0.102); these are pressuromodulation mapped in reference to B-cell polarization state and differentiation stage.

Conclusions: The esebssiwaago $T_{\mathrm{Q}}$-based pressuromodulation map of $\mathrm{B}$-cell differentiation simulates the in vivo B-cell maturation process for the classical pathway (T-cell mediated pressuromodulation effect pathway) and applies to the parallel non-classical pathway (T-cell independent antigen-mediated pressuromodulation effect pathway). Henceforth the B-cell pressuromodulation map can be utilized as the template for the study of specific B-cell events including bi-allelic V(D)J gene recombination, IGHM internal consensus recognition sequence, IGHD homologous recombination or initial allelic exclusion, further consensus recognition sequence isotype switchings, and somatic hypermutation, as in Part II.

Keywords: Horizontal alignment, esebssiwaagoT ${ }_{Q}$, Pressurotopic, Anisotropy, Mesotropy, Stabilizing isotropy, Suprapressuromodulated gene, Infra-pressuromodulated gene, Macro-pressuromodulation, Micro-pressuromodulation, Cell polarization, Gene recombination, Classical B-cell maturation pathway, Alternative non-classical B-cell maturation pathway

Correspondence: hsmd74@hotmail.com

Freelance Investigator in Translational Science and Medicine, 833 Carroll

Road, Charleston, West Virginia, USA 


\section{Background}

Pressuromodulation of the cell results in changes in intracellular pressure that are transduced to the nuclear membrane by the way of cytoplasmic microtubular network [1]. These alterations in cell pressure align genes (gene loci) horizontally for transcription [2], open cell membrane (CM) channels, and depolarize cells for exocytosis $[1,2]$. Positive pressuromodulation increases intracellular pressure [synergistic CM, endocytic, CM Rto-CM R-mediated polarization, $\mathrm{CM}$ receptor (R)-mediated polarization, and short duration CM R-adjusted for receptor number-mediated]; whereas, mixed pressuromodulation decreases intracellular pressure via mitochondrial branching/oxidative challenge (long duration CM R-adjusted for receptor number-mediated), and negative pressuromodulation decreases intracellular pressure via CM perturbation (transient duration).

In the case of the myeloid bone marrow cells, the various hematopoietic lineage cell types in the sub-cortical marrow caverns are subject to equivalent surrounding tissue cell pressuromodulation by the non-synergistic macropressuromodulation effect, which results in a decrease in effective intracellular pressure due to the presence of extracellular pressure [2, 3]; whereas, their common progenitor stem cell group at the cortical subcortical cavern interface is subject to synergistic cell membrane pressuromodulation in the vascularly pressurized biological system [2, 3], which results in an increase in intracellular pressure by the synergistic macro-pressuromodulation effect (Elastance cell $^{*}$ Pressure $_{\text {intracellular }}=k$ ). Myeloid bone marrow cells are subject to autocrine and endocrine small molecule, factor and cytokine cellular micro-pressuromodulation effects along the concentration gradient from permeaselective blood-to-lymphatic capillaries across the marrow $\left(\right.$ Compliance $_{\text {cell membrane }}$ Pressure $_{\text {intracellular }}=k$ ) as are all cells in the system, macro-pressuromodulation and micro-pressuromodulation effects related by Compliance $_{\text {cell membrane }}+$ Elastance $_{\text {cell }}{ }^{*}$ Pressure $_{\text {intracellular }}=k$ $[1,2]$.

As gene transcription is a pressuromodulated process, it can be predicted by determining the episodic subepisode block sums split-integrated weighted averageaveraged gene overexpression tropy quotient (esebssiwaago $\left._{\mathrm{Q}}\right)$. The esebssiwaago $T_{\mathrm{Q}}$ is a measure of the $5^{\prime} \rightarrow 3^{\prime}$ reading direction intergene distance tropy that needs to be overcome for horizontal alignment of a gene for maximal transcription [3]; it is also an arbitrary unit measure of the intracellular pressure needed for maximal gene expression. Thus, the esebssiwaago $T_{\mathrm{Q}}$ is a property of the gene. The gene esebssiwaago $T_{\mathrm{Q}}$ has been validated by the study of the gene expression of a multinucleated mitogenic cell type, the VEGF-dependent endocytic lymphatic capillary endothelial cell (LEnC), as compared to that of a mono-nucleated non-mitogenic cell type, the blood microvascular capillary endothelial cell (BMEnC), differentiated cell types at opposite ends of the pressuromodulation pressure spectrum. The gene esebssiwaago $T_{\mathrm{Q}}$ is $100 \%$ sensitive $(<0.25$ for all $\mathrm{BMEnC}$ overexpressed genes; infra-pressuromodulated genes) and $100 \%$ specific $(\geq 0.25<0.75$ for all LEnC overexpressed genes; supra-pressuromodulated genes) (100\% accurate). The gene esebsiwaago $T_{\mathrm{Q}}$ is accurate to 3 -significant digits (Infra, $<0.245$; Supra, $\geq 0.245<0.745$ ) for Episode 2 category ( $>11,864 \leq 265,005$ base), Episode 3 category ( $\leq 11,864$ base) and Episode 6 category $(\geq 2,241,933$ base) genes, which are the majority of human genes; and it is accurate to 2-significant digits (Infra, <0.25; Supra, $\geq$ $0.25<0.75)$ for Episode 4 category $(>265,005<607,463$ base) and Episode 5 category ( $\geq 607,463<2,241,933$ base) genes, which are the minority of them [2, 3].

The classical B-cell maturation pathway [4] involves three intertwined overlapping phases [5-10]. The first phase is in the sub-cortical myeloid bone marrow through Allele 1 (IGHM) internal consensus sequence recognition (iCSR) CM IgM+ and Allele $2 \mathrm{~V}(\mathrm{D}) \mathrm{J}$ [7], which is weighted towards the antigen presenting cell (APC)-more or less primed CD4R+ T-cell-mediated B-cell polarization effect [6-8] when mitochondrial content is lowest [11]. The second phase is in the lymph node through Allele 2 (IGHD) post-V(D)J homologous recombination (HR) CM IgD+ IgM+ (or allelic exclusion iCSR IgM+ IgM+) and further CSR isotype switching/somatic hypermutation (SHM) [10], which is also weighted towards the CD4R+ T-cellmediated B-cell polarization effect [5-8]. And then the third phase is in the periphery/tissue nidus when primary antibody or secondary antibody, etc. is secreted, which is weighted towards the T-cell independent B-cell CM receptor antigen pressuromodulation effect, either positive antigen-mediated pressuromodulation or negative antigenmediated pressuromodulation $+/$ - small molecule, cytokine and factor pressuromodulation effect [12].

CD34R+ stem cells that differentiate into B-cell lineage cell subsets overexpress: (1) PRDM1 (alias BLIMP-1), the gene that expresses the B-cell master transcription factor antagonist of $C-M Y C$ and other genes [13], which decreases intracellular pressure by decreasing cell surface C-MYC R; (3) CD40, the gene that expresses the Bcell CM receptor CD40R for the CD4R+ T-cell CM CD40 Ligand (CD40LG), which increases intracellular pressure by B-cell-to-CD4R+ T-cell polarization [5, 8]; and (3) PTPRC, the gene that expresses the B-cell CM receptor CD45R (B220) for dendritic cell CM receptor [14], which maintains intracellular pressure by B-cell-todendritic cell polarization. Therefore, the overexpression of PRDM1 serves to decrease B-cell intracellular pressure (the Yang), while the overexpression of CD40 serves to increase B-cell intracellular pressure (the Yin): this is 
the oscillating relationship that defines the B-cell in context of the quintessential requirement of the CD4R+ T-cell in the classical B-cell maturation pathway [4].

Based on the Yin Yang relationship between CD4O and PRDM1 in context of refractory periods of biologic cellular processes, it is deduced that there exist three different periods of CD4R+ CD40LG T-cell-mediated CD40R B-cell polarization effect. The three different periods of B-cell polarization are: (1) the maximum polarization period $(\mathrm{CD} 40 \mathrm{R}+)$, which is the B-cell dedifferentiation period when markers such as CD34R, PRDM1 and PTPRC are expressed; (2) the full refractory period (CD40R-), which is the B-cell $G_{0}$ cell phase period towards differentiated cell stage when markers such as CD38R and CR2R (alias CD21R) are expressed; and (3) the half refractory period (CD40R \pm ), which is the B-cell cell division (DNA synthesis-to-mitosis) period towards proliferative cell stage markers when markers such as PCNA, MKI67 and ESPL1 are expressed.

The parallel alternative non-classical B-cell maturation pathway (1-allele T-cell independent antigen-mediated pressuromodulation effect pathway) [15] completes to the point of Allele 1 iCSRed IgM+ only B-cells (IgM $+/$ IgD-)/plasma cells in the myeloid marrow and then progresses to further CSRed isotype switched Ig_+ only B-cells/plasma cells (Ig_+/IgD-) in the periphery/nidus, but requires a significant positive antigen pressuromodulation effect to re-express PRDM1 vis a vis toll-like receptor (TLR)-mediated endocytosis for example to complete the Allele $1 \mathrm{~V}(\mathrm{D}) \mathrm{J}$ iCSR IGHM process as neither the CD4R+ T-cell TCR $[16,17]$ nor the T-cell CD40LG (Hyper-IgM Type 1) [18, 19] or B-cell CD40R (Hyper-IgM Type 3) [19] are required.

The classical pathway (2-allele T-cell mediated pressuromodulation effect pathway) and the parallel nonclassical pathway (1-allele T-cell independent antigenmediated pressuromodulation effect pathway) are similar with respect to the PRDM1 Yang and analogous with respect to the Yin, the former pressuromodulated by the CD4R+ T-cell-mediated effect, and the later by the toll-like receptor (TLR)-mediated effect (i.e. endocytic). In this study, B-cell differentiation is studied by esebssiwaago $T_{\mathrm{Q}}$-based pressuromodulation mapping of $\mathrm{B}$-cell stage marker genes. Pressuromodulation mapping is performed by arranging B-cell differentiation marker genes pressurotopically by esebssiwaago $T_{Q}$ in descending and ascending order in reference to periods of B-cell polarization and consideration of B-cell maturation stage.

\section{Methods}

Data acquisition and overall methodology

Locations of 25 B-cell differentiation stage genes, CD34, PRDM1 (alias BLIMP-1), PTPRC (alias CD45; B220), CD40 (alias TNFRSF5), CD19 (alias B4), MS4A1 (alias
CD20), CR2 (aliases CD21; EBV R 2), CD27, CD38, CD79A (alias B-cell ARC-AP $\alpha$ ) and $C D 79 B$ (alias B-cell ARC-AP ß), RAG2, RAG1, AICDA, APOBEC3A, APOBEC3B, APO$B E C 3 C, A P O B E C 3 D$, APOBEC $3 F$, APOBEC3G, APOBEC3H, PCNA, MKI67, ENPP1 and ESPL1 [4], and locations of downstream and upstream genes were mined at GeneCards (https://www.genecards.org/) and at LNCipedia.org (http://www.lncipedia.org/), pseudogenes included and enhancers excluded (Additional file 1: Table S1) [2].

The downstream and upstream intergene base distances were tabulated, and episodic sub-episode sums split-integrated weighted average-averaged gene overexpression tropy quotients (esebssiwaago $T_{\mathrm{Q}} \mathrm{s}$ ) for each gene were calculated, as follows: First, the $3{ }^{\prime}->$ $5^{\prime}$ and $5^{\prime}->3^{\prime}$ direction paired point tropy quotients $\left(\operatorname{prp} T_{\mathrm{Q}} \mathrm{s}\right)$ were determined; second, initial anisotropic and mesotropic sub-episode blocks (SEB; ASEB, MSEB) were determined, which are constant per episode; third, final anisotropic and mesotropic sub-episode blocks (SEB; ASEB, MSEB) were determined, which are variable; and fourth, the $5^{\prime}->3^{\prime}$ direction esebssiwaago $T_{\mathrm{Q}} \mathrm{s}$ to the final esebssiwaago $T_{\mathrm{Q}}$ was determined.

Upon determination of the gene esebssiwaago $T_{\mathrm{Q}^{\mathrm{S}}}$ a pressuromodulation map in order of gene overexpression was generated to simulate the order of pressuromodulation-mediated gene expression changes during B-cell differentiation.

\section{Determination of the $3^{\prime}->5^{\prime}$ and $5^{\prime}->3^{\prime}$ direction paired point tropy quotients ( $p r p T_{\mathrm{Q}} \mathrm{S}$ )}

Non-transcribing intergene distances were determined upstream and downstream from the gene of interest. The $3^{\prime}->5^{\prime}$ direction and $5^{\prime}->3^{\prime}$ direction paired point tropy quotients $\left(p r p T_{\mathrm{Q}}\right.$; fract) were determined, the $3^{\prime}->5^{\prime}$ $\operatorname{prp} T_{\mathrm{Q}} \mathrm{s}$ for the polymerase non-transcribing reverse $3^{\prime}->$ $5^{\prime}$ direction (Eq. 1) and the $5^{\prime}->3^{\prime} \operatorname{prp}_{\mathrm{Q}} \mathrm{s}$ for the polymerase transcribing $5^{\prime}->3^{\prime}$ direction (Eq. 2),

$$
\begin{aligned}
3^{\prime}->5^{\prime} \operatorname{prp} T_{Q}= & \frac{3^{\prime}->5^{\prime} \text { upstream } 1^{\text {st }} \text { intergene distance }}{3^{\prime}->5^{\prime} \text { downstream } 1^{\text {st }} \text { intergene distance }} \\
& \ldots \frac{3^{\prime}->5^{\prime} \text { upstream } \mathrm{n}^{\text {th }} \text { intergene distance }}{3^{\prime}->5^{\prime} \text { downstream } \mathrm{n}^{\text {th }} \text { intergene distance }}
\end{aligned}
$$

$$
\begin{aligned}
5^{\prime}->3^{\prime} \operatorname{prp} T_{Q}= & \frac{5^{\prime}->3^{\prime} \text { upstream } 0^{\text {th }} \text { intergene distance order }}{5^{\prime}->3^{\prime} \text { downstream } 0^{\text {th }} \text { intergene distance order }} \\
& \cdots \frac{5^{\prime}->3^{\prime} \text { upstream } \mathrm{n}^{\text {th }} \text { intergene distance order }}{5^{\prime}->3^{\prime} \text { downstream } \mathrm{n}^{\text {th }} \text { intergene distance order }}
\end{aligned}
$$

where the total number of $p r p T_{\mathrm{Q}}$ points are the total of the reverse order $3^{\prime}->5^{\prime} p r p T_{\mathrm{Q}}$ points beginning at the $1^{\text {st }}$ Order and the forward order $5^{\prime}->3^{\prime} \operatorname{prp}_{\mathrm{Q}}$ points beginning at the $0^{\text {th }}$ Order, and 
where the total number of $p r p T_{\mathrm{Q}}$ points are those that achieve the $n^{\text {th }}$ order of $5^{\prime}->3^{\prime} \operatorname{prp}_{\mathrm{Q}}$ beginning at the $0^{\text {th }}$ Order for either $2,3,4,5$ or 6 episodes to the ending confirmation for the respective gene base category.

\section{Determination of initial anisotropic and mesotropic sub-episode blocks (SEB; ASEB, MSEB) for characterization of episodic character}

The anisotropic and mesotropic sub-episode blocks (SEB; ASEB, MSEB) were determined,

where the $0^{\text {th }}$ order $p r p T_{\mathrm{Q}}$ containing $\mathrm{SEB}$ is the $1^{\text {st }}$ $5^{\prime}->3^{\prime} \operatorname{prp}_{\mathrm{Q}} \mathrm{SEB}$, and

where a $\mathrm{SEB}$ is one with a single $p r p T_{\mathrm{Q}}$, or one with double, triple or multiple $p r p T_{\mathrm{Q}} \mathrm{S}$,

- where an anisotropic sub-episode block (ASEB) is one with one $\operatorname{prp} T_{\mathrm{Q}}$, two $\operatorname{prp} T_{\mathrm{Q}} \mathrm{S}$, three $\operatorname{prp} T_{\mathrm{Q}} \mathrm{s}$, or multiple $p r p T_{\mathrm{Q}} \mathrm{s}$ of $<0.25$ each, and

- where a mesotropic sub-episode block (MSEB) is one with one $p r p T_{\mathrm{Q}}$, two $p r p T_{\mathrm{Q}} \mathrm{S}$, three $\operatorname{prp} T_{\mathrm{Q}} \mathrm{s}$, or multiple $\operatorname{prp}_{\mathrm{Q}} \mathrm{S}$ of $\geq 0.25<0.75$ each,

where a $p r p T_{\mathrm{Q}} \geq 0.75$ is a $5^{\prime}->3^{\prime}$ or $3^{\prime}->5^{\prime}$ stabilizing isotropy $\operatorname{prp} T_{\mathrm{Q}}$ point that represents horizontal intergene distance pair tropy that precedes an $\mathrm{ASEB} p r p T_{\mathrm{Q}}$ or an MSEB $p r p T_{\mathrm{Q}}$,

- where a stabilizing isotropy (stIsotropy, stI) point is a $5^{\prime} \rightarrow 3^{\prime}$ direction $\operatorname{prp}_{\mathrm{Q}}>=0.75$, and

- where a reverse stabilizing isotropy (reverse stIsotropy) point is a $3^{\prime} \rightarrow 5^{\prime}$ direction $\operatorname{prp}_{\mathrm{Q}}>=0.75$,

where one episode is a singular anisotropic sub-episode block (ASEB) followed by a singular mesotropic subepisode block (MSEB), or vice versa [ie beginning or ending with an ASEB (anisotropic period), beginning or ending with an MSEB (mesotropic period)], ASEB and the MSEB periods with overlapping; and

where the number of initial sub-episode blocks (initial SEBs) for establishing a gene category with $100 \%$ sensitivity and 100\% specificity (100\% accuracy) are: 5 initial SEBs for an Episode 2 category gene, 7 initial SEBs for an Episode 3 category gene, 9 initial SEBs for an Episode 4 gene, 11 initial SEBs for an Episode 5 gene, and 13 initial SEBs for an Episode 6 gene [2].

\section{Determination of final anisotropic and mesotropic sub-episode blocks (SEB; ASEB, MSEB)}

The final number of anisotropic and mesotropic subepisode blocks (SEB; ASEB, MSEB) were determined after the number of initial sub-episode blocks were established as follows:
(1)Non-contributory ( $\mathrm{NC}) p r p T_{\mathrm{Q}}$ point intergene distance pair tropies were considered,

where a single $5^{\prime}->3^{\prime}$ ASEB $p r p T_{\mathrm{Q}}$ point or multianisotropic point ASEB is a non-contributory (NC) anisotropic sub-episode block (NCA) when it is immediately preceded by reverse anisotropy $3^{\prime}->5^{\prime} p r p T_{\mathrm{Q}} \mathrm{S}$ of equivalent or greater magnitude, in which case there may also be intervening non-contributory reverse stI or stI points if the $5^{\prime}->3^{\prime}$ ASEB $p r p T_{\mathrm{Q}}$ point remains anisotropic upon consideration of full-magnitude of each reverse stI and/or stI (NCstI), and

where a $5^{\prime}->3^{\prime}$ MSEB $p r p T_{\mathrm{Q}}$ point intergene distance tropy is never a non- contributory sub-episode block $5^{\prime}->3^{\prime} \operatorname{prp} T_{\mathrm{Q}}$;

(2)Direct reverse stIsotropy and/or stIsotropy were considered,

where a single $5^{\prime}->3^{\prime}$ ASEB $p r p T_{\mathrm{Q}}$ point of a single point or multiple point ASEB converts to a mesotropic point $(\mathrm{ACM})$ when there is adjusted preceding direct reverse stI and/or stI of sufficient magnitude;

(3)Indirect reverse stIsotropy and/or stIsotropy were considered,

where a mesotropic $\operatorname{prp}_{\mathrm{Q}}$ point of a single or multiple point MSEB converts to stIsotropy due to the presence of preceding stIsotropy, then further adjusted to serve as halfmagnitude (0.5-factor adjusted) stIsotropy for an anisotropic point of a single or multiple point ASEB (stIM; stIMfA), which may or may not convert to a mesotropic point, and

where a mesotropic $p r p T_{\mathrm{Q}}$ point of a single or multiple point MSEB converts to stIsotropy due to the presence of preceding stIsotropy, then further adjusted to serve as half-magnitude (0.5-factor adjusted) stIsotropy for another mesotropic point of a single or multiple point MSEB (stIM; stIMfM).

Determination of the $5^{\prime}->3^{\prime}$ direction esebssiwaago $T_{\mathrm{Q}} \mathrm{s}$ to the final esebssiwaago $T_{\mathrm{Q}}$

The complete $5^{\prime}->3^{\prime}$ direction episodic sub-episode sums split-integrated weighted average-averaged gene overexpression tropy quotients (esebssiwaago $T_{Q} \mathrm{~s}$; fract) were determined to the final esebssiwaago $T_{\mathrm{Q}}$ in upstream anisotropic, upstream mesotropic, downstream anisotropic and downstream mesotropic parts.

First, the upstream part anisotropic sub-episode block sum (uppASEBS), the upstream part mesotropic subepisode block sum (uppMSEBS), the downstream part anisotropic sub-episode block sum (dppASEBS), and the 
downstream part mesotropic sub-episode block sum (dPpMSEBS) were determined. Then, the $5^{\prime}$ - > 3' uppASEBS adjusted for $5^{\prime}->3^{\prime}$ uppASEBS stabilizing isotropy (stIsotropy) (Eq. 3a), 5' -> 3' uppMSEBS adjusted for 5' -> 3' uppMSEBS stIsotropy (Eq. 3b), 5' -> 3' dppASEBS adjusted for $5^{\prime}$ - > 3' dppASEBS stIsotropy (Eq. 3c), and the $5^{\prime}->3^{\prime} d p p M S E B S$ adjusted for $5^{\prime}$ - > $3^{\prime}$ $d p p M S E B S$ stIsotropy $(E q .3 d)$ were determined,

$5^{\prime}->3^{\prime}$ uppASEBS adjusted for $5^{\prime}->3^{\prime}$ stIsotropy

$$
=\sum_{0}^{n} k_{1}+\ldots+k_{n}+\sum_{0}^{n}\left(a_{1,2,3}\right)\left(r_{1}\right)+\ldots+\left(a_{1,2,3}\right)\left(r_{n}\right)
$$

$5^{\prime}->3^{\prime}$ uppMSEBS adjusted for $5^{\prime}->3^{\prime}$ stIsotropy

$$
=\sum_{0}^{n} l_{1}+\ldots+l_{n}+\sum_{0}^{n}\left(a_{1,2,3}\right)\left(s_{1}\right)+\ldots+\left(a_{1,2,3}\right)\left(s_{n}\right)
$$

$5^{\prime}->3^{\prime} d p p A S E B S$ adjusted for $5^{\prime}->3^{\prime}$ stIsotropy

$$
=\sum_{0}^{n} p_{1}+\ldots+p_{n}+\sum_{0}^{n}\left(a_{1,2,3}\right)\left(r_{1}\right)+\ldots+\left(a_{1,2,3}\right)\left(r_{n}\right)
$$

$5^{\prime}->3^{\prime}$ dppMSEBS adjusted for $5^{\prime}->3^{\prime}$ stIsotropy

$$
=\sum_{0}^{n} q_{1}+\ldots+q_{n}+\sum_{0}^{n}\left(a_{1,2,3}\right)\left(s_{1}\right)+\ldots+\left(a_{1,2,3}\right)\left(s_{n}\right)
$$

where $k$ is an upstream $5^{\prime}->3^{\prime}$ direction point intergene segment distance in an ASEB, and

where $l$ is an upstream $5^{\prime}->3^{\prime}$ direction point intergene segment distance in a MSEB,

- where $r$ is the upstream $5^{\prime}->3^{\prime}$ direction stIsotropy point intergene segment distance in an ASEB or in a $\operatorname{MSEB}\left(r_{\mathrm{n}}\right.$ for an ASEB or MSEB with more than one stIsotropy point)

where $p$ is a downstream $5^{\prime}->3^{\prime}$ direction point intergene segment distance in an ASEB, and

where $q$ a downstream $5^{\prime}->3^{\prime}$ direction point intergene segment distance in a MSEB,

- where $s$ is the downstream $5^{\prime}->3^{\prime}$ direction stIsotropy point intergene segment distance in an ASEB or in a MSEB ( $s_{\mathrm{n}}$ for an ASEB or MSEB with more than one stIsotropy point)

$\circ$ where $a$ is $a_{1}=0$ for no preceding $5^{\prime}->3^{\prime}$ or

$3^{\prime}$ - > 5' stIsotropy

- where $a$ is $a_{2}=0.125$ for preceding $5^{\prime}->3^{\prime}$ or $3^{\prime}$

$->5^{\prime}$ stIsotropy in the presence of preceding $3^{\prime}->5^{\prime}$

reverse anisotropy or preceding intervening $3^{\prime}->5^{\prime}$ reverse anisotropy

- where $a$ is $a_{3}=0.25$ for immediately preceding $5^{\prime}->3^{\prime}$ or $3^{\prime}->5^{\prime}$ stIsotropy in the absence of intervening $3^{\prime}->5^{\prime}$ reverse anisotropy.
The 5' - > 3' uppASEBS adjusted for uppASEBS 3' - > 5' stabilizing isotropy (stIsotropy) (Eq. 3e), 5' - > 3' uppMSEBS adjusted for uppMSEBS 3' - > 5' stIsotropy (Eq. 3f), 5' - > 3' dppASEBS adjusted for dppASEBS 3' - > 5' stIsotropy (Eq. 3 g), and the 5' - > 3' dppMSEBS adjusted for $d p p M S E B S 3^{\prime}$ - > 5' stIsotropy were determined (Eq. 3 h),

$5^{\prime}->3^{\prime}$ uppASEBS adjusted for $3^{\prime}->5^{\prime}$ stIsotropy

$$
=\sum_{0}^{n} k_{1}+\ldots+k_{n}+\sum_{0}^{n}\left(a_{1,2,3}\right)\left(t_{1}\right)+\ldots+\left(a_{1,2,3}\right)\left(t_{n}\right)
$$

$5^{\prime}->3^{\prime}$ uppMSEBS adjusted for $3^{\prime}->5^{\prime}$ stIsotropy

$$
=\sum_{0}^{n} l_{1}+\ldots+l_{n}+\sum_{0}^{n}\left(a_{1,2,3}\right)\left(t_{1}\right)+\ldots+\left(a_{1,2,3}\right)\left(t_{n}\right)
$$

$5^{\prime}->3^{\prime} d p p M S E B S$ adjusted for $3^{\prime}->5^{\prime}$ stIsotropy

$=\sum_{0}^{n} p_{1}+\ldots+p_{n}+\sum_{0}^{n}\left(a_{1,2,3}\right)\left(t_{1}\right)+\ldots+\left(a_{1,2,3}\right)\left(t_{n}\right)$

$5^{\prime}->3^{\prime}$ dppASEBS adjusted for $3^{\prime}->5^{\prime}$ stIsotropy

$$
=\sum_{0}^{n} q_{1}+\ldots+q_{n}+\sum_{0}^{n}\left(a_{1,2,3}\right)\left(t_{1}\right)+\ldots+\left(a_{1,2,3}\right)\left(t_{n}\right)
$$

- where $t$ is the upstream $3^{\prime}->5^{\prime}$ direction stIsotropy point intergene segment distance in an ASEB or in a $\operatorname{MSEB}\left(t_{\mathrm{n}}\right.$ for an ASEB or MSEB with more than one stIsotropy point)

- where $t$ is also the downstream $3^{\prime}->5^{\prime}$ direction stIsotropy point intergene segment distance in an ASEB or in a MSEB $\left(t_{\mathrm{n}}\right.$ for an ASEB or MSEB with more than one stIsotropy point)

Second, the upstream part anisotropic sub-episode block sums split-integrated weighted average (uppasebssiwa) (Eq. 4a), the upstream part mesotropic sub-episode block sums split-integrated weighted average (uppmsebssiwa) (Eq. 4b), the downstream part anisotropic sub-episode block sums split-integrated average (dppasebssiwa) (Eq. 4c) and the downstream part mesotropic sub-episode block sums split-integrated weighted average (dppmsebssiwa) (Eq. 4d) were determined,

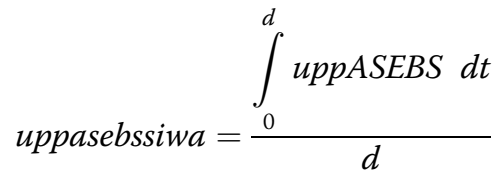

uppmsebssiwa $=\frac{\int_{0}^{h} \text { uppMSEBS dt }}{h}$ 
dppasebssiwa $=\frac{\int_{0}^{d} d p p A S E B S d t}{d}$

dppmsebssiwa $=\frac{\int_{0}^{h} d p p M S E B S d t}{h}$

- where $d$ is the number of split-integrated upstream part anisotropic sub-episode block sums (uppASEBS) and the number of split-integrated downstream stream part anisotropic sub-episode block sums (dppASEBS), and

- where $h$ is the number of split-integrated upstream part mesotropic sub-episode block sums (UPPMSEBS) and the number of split-integrated downstream stream part mesotropic sub-episode block sums (dppMSEBS).

Third, the weighted average of the uppasebssiwa and uppmsebssiwa was determined as the upstream part episodic sub-episode block sums split-integrated weighted average-average (uppesebssiwaa) (Eq. 5a), and the weighted average of the dppasebssiwa and dppmsebssiwa was determined as the downstream part episodic sub-episode block sums split-integrated weighted average-average (dppesebssiwaa) (Eq. 5b) were determined,

$$
\begin{aligned}
& \text { uppesebssiwaa }=\frac{\text { uppasebssiwa }+ \text { uppmsebssiwa }}{2} \\
& \text { dppesebssiwaa }=\frac{\text { dppasebssiwa }+ \text { dppmsebsiwa }}{2}
\end{aligned}
$$

Fourth, the complete episodic sub-episode block sums split-integrated weighted average-averaged gene overexpression tropy quotients (esebssiwaago $\left.T_{\mathrm{Q}} \mathrm{s}\right)(E q$. 6) were determined to the final complete esebssiwaago $T_{\mathrm{Q}}$,

$$
\text { esebssiwaago }_{Q}=\frac{5^{\prime}->3^{\prime} \text { uppesebssiwaa }}{5^{\prime}->3^{\prime} \text { dppesebssiwaa }}
$$

- where the esebssiwaago $T_{\mathrm{Q}}$ at Episode 2 is the final esebssiwaago $T_{\mathrm{Q}}$ for genes $>11,864 \leq 265,005$ bases

- where the esebssiwaago $T_{\mathrm{Q}}$ at Episode 3 is the final esebssiwaago $T_{\mathrm{Q}}$ for genes $\leq 11,864$ bases.

- where the esebssiwaago $T_{\mathrm{Q}}$ at Episode 4 is the final esebssiwaago $T_{\mathrm{Q}}$ for genes $>265,005<607,463$ bases

- where the esebssiwaago $T_{\mathrm{Q}}$ at Episode 5 is the final esebssiwaago $T_{\mathrm{Q}}$ for genes $\geq 607,463<2,241,933$ bases
- where the esebssiwaago $T_{\mathrm{Q}}$ at Episode 6 is the final esebssiwaago $T_{\mathrm{Q}}$ for genes $\geq 2,241,933$ bases.

Fifth, genes were determined to be either infra-pressuromodulated or supra pressuromodulated,

- where a gene with an anisotropic final esebssiwaago $T_{\mathrm{Q}}$ for genes $<0.25$ is an Infra gene, and

- where a gene with a mesotropic final esebssiwaago $T_{\mathrm{Q}}$ for genes $\geq 0.25<0.75$ is a Supra gene.

\section{Pressuromodulation mapping}

B-cell differentiation genes were arranged pressurotopically in descending and ascending order by the gene esebssiwaago $T_{Q}$ in reference to the three periods of $\mathrm{B}$ cell polarization and B-cell maturation stage. First, stem cell marker gene, CD34, transcription factor adapter gene, PRDM1 and B-cell polarization genes, PTPRC and $C D 40$ were arranged. Then, B-cell cluster of differentiation receptor genes, CD19, MS4A1, CR2, CD27 and $C D 38$, and cluster of differentiation receptor $\mathrm{B}$-cell antigen receptor complex-associated proteins, $C D 79 A$ and $C D 79 B$, were arranged. Third, VDJ recombinase genes, RAG2 and RAG1, and consensus sequence recognition (CSR)/somatic hypermutation enzyme genes, $A P O B E C 3 A / A P O B E C 3 B, A I C D A$, $A P O B E C 3 C / A P O B E C 3 D / A P O B E C 3 F / A P O B E C 3 G$ and $A P O B E C 3 H$, were interposed. Last, cell proliferation marker genes, PCNA, ENPP1, MKI67 and ESPL1 were placed.

The stem cell, Pro-B cell, Large pre-B cell, Small pre-B cell, Immmature B-cell, Mature naive B-cell $[\rightarrow$ B-cell/plasmablast], and Evolved Mature naive B-cell $[\rightarrow$ B-plasma cell/plasmablast] stages were denoted in reference to the three B-cell polarization periods, the maximum polarization $(C D 40 R+)$, the full-refractory (CD40R-) and the half-refractory (CD40R \pm ).

After the B-cell pressuromodulation map was generated, the general intervals of the following events were denoted on the map: (1) internal CSR (iCSR) for Allele 1 (IGHM) and CM IgM+ IgD-; (2) homologous recombination for Allele 2 (IGHD) and $\mathrm{CM}$ IgM+ IgD+; and (3) initial stage of further sequential CSRs to CM IgG3+, IgG1+, etc., either allelic or bi-allelic.

\section{Results}

Stem cell cluster of differentiation gene, CD34

CD34 is a 2 episode, 5 initial SEB and 3 final SEB gene that begins with a mesotropic SEB. CD34 has one instance of non-contributory anisotropy. CD34 is a $2 \mathrm{M}$ [5(-2): 3] NCA gene with a final esebssiwaago $T_{\mathrm{Q}}$ of 0.65 (0.648) (Table 1, Table 2; Fig. 1). 
Table 1 Chromosome 1 (-) strand chromatin stem cell cluster of differentiation gene, CD34, esebssiwaagoT for pressuromodulation mapping

\begin{tabular}{llllll}
\hline $\begin{array}{l}\text { Germline } \\
\text { Gene }\end{array}$ & $\begin{array}{l}\text { Germline } \\
\text { gene locus }\end{array}$ & $\begin{array}{l}\text { Ch No. } \\
\text { (Strand) }\end{array}$ & $\begin{array}{l}\text { Total no. of transcribed bases at gene } \\
\text { locus or n/a (episode category) }\end{array}$ & $\begin{array}{l}\text { Initial no. of sub-episode blocks (converted } \\
\text { final no. of sub-episode blocks, or n/a) }\end{array}$ & $\begin{array}{l}\text { Germline gene 2-digit } \\
\text { (3-digit) esebssiwaagot } \\
\text { or n/a }\end{array}$ \\
\hline CD34 & $\begin{array}{l}\text { CD34//Inc- } \\
\text { C1orf132-5 }\end{array}$ & 1 q32.2 (-) & $34,319(2)$ & $5(3)$ & 0.65 (0.648)
\end{tabular}

${ }^{a}>11,864 \leq 265,005$ total transcribed bases, Episode category 2 gene; Episode category 3 gene bases, $\leq 11,864$ total transcribed bases, Episode category 3 gene

\section{B-cell transcription factor adapter gene, PRDM1}

PRDM1 is a 2 episode, 5 initial and final SEB gene that begins with an anisotropic SEB. PRDM1 has one instance of anisotropy converted-to-mesotropy, and two instances of non-contributory anisotropy. PRDM1 is a 2 A (5) ACM NCA $\times 2$ gene with a final esebssiwaago $T_{\mathrm{Q}}$ of 0.36 (0.356) (Table 3, Table 4; Fig. 1).

\section{B-cell polarization receptor genes, CD40 and PTPRC}

CD40 is a 2 episode, 5 initial SEB and final SEB gene that begins with an anisotropic SEB. CD40 is a 2 A (5) gene with a final esebssiwaago $T_{\mathrm{Q}}$ of $0.26(0.257)$.

PTPRC is a 2 episode, 5 initial SEB and 2 final SEB gene that begins with an anisotropic SEB. PTPRC has one instance of anisotropy converted-to-mesotropy, and one instance of non-contributory anisotropy. PTPRC is a $2 \mathrm{~A}$ [5(-3): 2] ACM NCA gene with a final esebssiwaago $T_{\mathrm{Q}}$ of 0.35 (0.345) (Table 5, Table 6; Fig. 1).

\section{B-cell cluster of differentiation receptor genes CD19, MSA1, CR2, CD27 and CD38}

CD19 (B4) is a 3 episode, 7 initial and 5 final SEB gene that begins with a mesotropic SEB. CD19 has one instance of non-contributory anisotropy, and one instance of non-contributory reverse/stIsotropy. CD19 is a $3 \mathrm{M}$ [7(- 2): 5] NCA NCstI gene with a final esebssiwaago $T_{\mathrm{Q}}$ of 0.15 (0.153).

MS4A1 (CD20) is a 2 episode, 5 initial SEB and 3 final SEB gene that begins with an anisotropic SEB. MS4A1 has one instance of non-contributory anisotropy. $M S 4 A 1$ is a 2 A [5(-2): 3] NCA gene with a final esebssiwaago $T_{\mathrm{Q}}$ of 0.30 (0.299).

CR2 (CD21; EBV R 2) is a 2 episode, 5 initial and final $\mathrm{SEB}$ gene that begins with an anisotropic SEB. CR2 is a 2 A (5) gene with a final esebssiwaago $T_{\mathrm{Q}}$ of $0.11(0.109)$.

CD27 is a 2 episode, 5 initial and final SEB gene that begins with a mesotropic SEB. CD27 has two instances of non-contributory anisotropy. CD27 is a
$2 \mathrm{M}(5) \mathrm{NCA} \times 2$ gene with a final esebssiwaago $T_{\mathrm{Q}}$ of 0.19 (0.194).

CD38 is a 2 episode, 5 initial SEB and final SEB gene that begins with an anisotropic SEB. CD38 has one instance of non-contributory anisotropy. $C D 38$ is a $2 \mathrm{~A}$ (5) NCA gene with a final esebssiwaago $T_{\mathrm{Q}}$ of 0.21 (0.212) (Table 7, Table 8; Fig. 1).

B-cell cluster of differentiation pre-B-cell receptor genes, $C D 79 B$ and $C D 79 A$

CD79A (B-cell ARC-AP $\alpha$ ) is a 3 episode, 7 initial SEB and final SEB gene that begins with a mesotropic SEB. $C D 79 A$ is a $3 \mathrm{M}(7)$ gene a final esebssiwaago $T_{\mathrm{Q}}$ of 0.14 (0.137).

$C D 79 B$ (B-cell ARC-AP $\beta$ ) is a 3 episode, 7 initial SEB and final SEB gene that begins with a mesotropic SEB. $C D 79 B$ has one instance of anistropy convertedto-mesotropy, and one instance of non-contributory anisotropy. $C D 79 B$ is a $3 \mathrm{M}$ (7) ACM NCA gene a final esebssiwaago $T_{\mathrm{Q}}$ of 0.27 (0.271) (Table 9, Table 10; Fig. 1).

\section{B-cell VDJ recombinase genes, RAG2 and RAG1}

RAG2 is a 2 episode, 5 initial and 4 final SEB gene that begins with an mesotropic SEB. RAG2 has two instances of non-contributory anisotropy, and one instance of non-contributory reverse/stIsotropy. $R A G 2$ is a $2 \mathrm{M}$ [5(-1): 4] NCA $\times 2$ NCstI gene with a final esebssiwaago $T_{\mathrm{Q}}$ of $0.31(0.306)$.

$\boldsymbol{R A G 1}$ is a 2 episode, 5 initial and $6^{*}$ final SEB gene that begins with an anisotropic SEB. RAG1 has one instance of anisotropy converted-to-mesotropy of the ending, and one instance of non-contributory anisotropy. $R A G 1$ is a $2 \mathrm{~A}\left[5(+1): 6^{*}\right] \mathrm{ACM}^{*} \mathrm{NCA}$ gene with a final esebssiwaago $T_{\mathrm{Q}}$ of $0.14(0.139)$ (Table 11, Table 12; Fig. 1).

Table 2 Chromosome 1 (-) strand chromatin stem cell cluster of differentiation gene, CD34, sequential esebssiwaagoT $\mathrm{S}$ to final 2digit (and 3-digit) esebssiwaagotQ

\begin{tabular}{lllllllllllll}
\hline Gene Symbol & No. of Episodes [Initial no. of SEBs (final no. of SEBs)] ${ }^{\text {a-e }}$ & $\int_{0}^{1}$ & $\int_{0}^{2}$ & $\int_{0}^{3}$ & $\int_{0}^{4}$ & $\int_{0}^{5}$ & $\int_{0}^{6}$ & $\int_{0}^{7}$ & $\int_{0}^{8}$ & $\int_{0}^{9}$ & $\int_{0}^{10}$ & $\int_{0}^{11}$ \\
\hline CD34 & 2 M [5(-2): 3] NCA & 0.68 & 0.67 & $0.65(0.648)$ & & & & &
\end{tabular}

${ }^{a}$ 1st episode beginning with an anisotropic sub-episode block (SEB), A, or beginning with a mesotropic SEB, M; ${ }^{b}$ non-contributory anisotropic sub-episode block (NCA); ${ }^{C}$ non-contributory single or multiple stabilizing isotropy points or reverse stabilizing isotropy point(s), NCstl; ${ }^{d}$ anisotropy converted-to-mesotropy, ACM; and indirect reverse stlsotropy and/or stlsotropy for anisotropy, stMfA, or for mesotropy, stMfM 


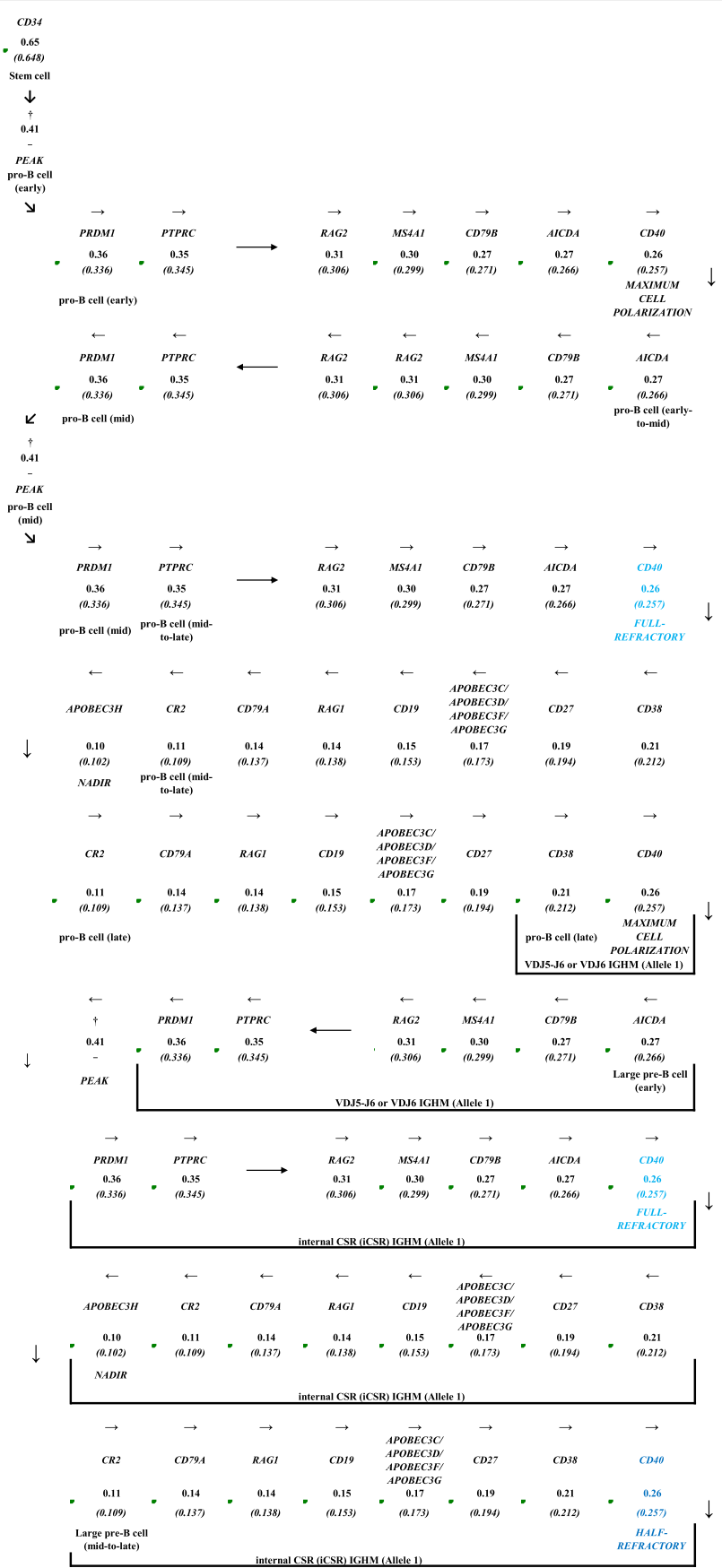

Fig. 1 Pressuromodulation map of B-cell differentiation stages. There are three completed maximal B-cell polarization periods with another to begin (CD40R+), two half-refractory B-cell polarization periods (CD40R \pm ), and four full-refractory B-cell polarization periods (CD40R-) to the 1st generation CM VDJ (VJ)-lgG3+, lgG1+, lgHA1+, lgG4+, lgG2+ or lgE+ (excluding IgA2+) Evolved Mature naïve B-cell preparing to CSR further in the lymph node (2nd phase) after the completing the Immature B-cell phase in the myeloid bone marrow (1st phase). The antigen pressuromodulation effectmediated extra-lymph nodal long-lived B-plasma cell/plasmablast secretory antibody phase (3rd phase) takes place in the periphery/tissue nidus. Note: The classical pathway B-cell maturation pressuromodulation map is shown, however the map applies to the parallel alternate B-cell maturation pathway wherein the T-cell independent antigen-mediated toll-like receptor (TLR) positive pressuromodulation effect (i.e. endocytic) substitutes for the CD4R+ CD40LG T-cell-mediated CD40R B-cell polarization pressuromodulation effect. †, upper esebssiwaagotQ units range, 0.41-0.36. Black, CD40 at maximum cell polarization potential (CD40R+). Dark blue, CD40 at half-refractory (CD40R \pm ). Light blue, CD40 at full-refractory (CD40R-). Thick black lined large rectangular box, extra-nodal secretory antibody phase 


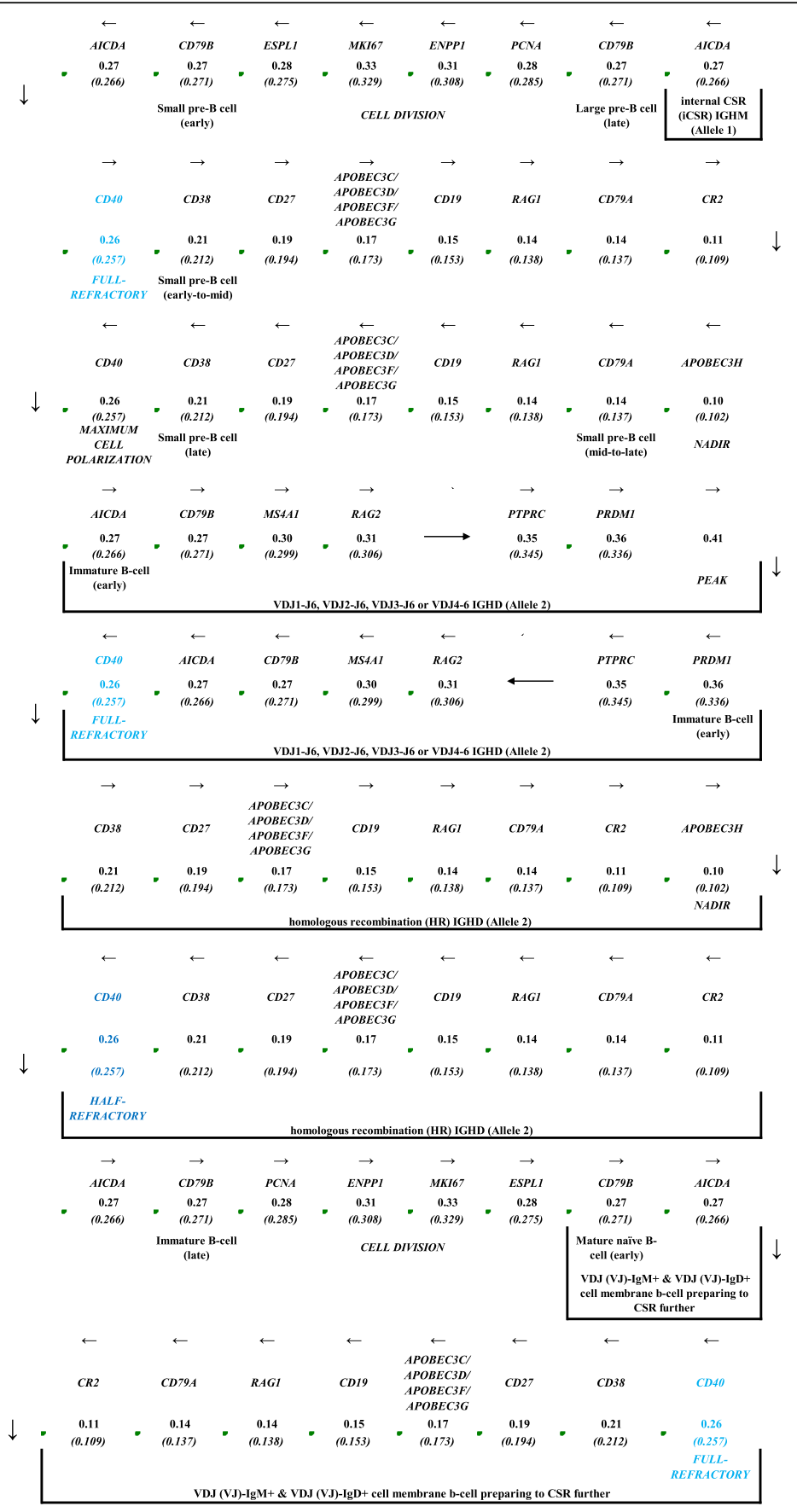

Fig. 1 Pressuromodulation map of B-cell differentiation stages. There are three completed maximal B-cell polarization periods with another to begin $(C D 40 R+)$, two half-refractory B-cell polarization periods (CD40R \pm ), and four full-refractory B-cell polarization periods (CD40R-) to the 1st generation CM VDJ (VJ)-lgG3+, lgG1+, lgHA1+, lgG4+, IgG2+ or lgE+ (excluding lgA2+) Evolved Mature naive B-cell preparing to CSR further in the lymph node (2nd phase) after the completing the Immature B-cell phase in the myeloid bone marrow (1st phase). The antigen pressuromodulation effectmediated extra-lymph nodal long-lived B-plasma cell/plasmablast secretory antibody phase (3rd phase) takes place in the periphery/tissue nidus. Note: The classical pathway B-cell maturation pressuromodulation map is shown, however the map applies to the parallel alternate B-cell maturation pathway wherein the T-cell independent antigen-mediated toll-like receptor (TLR) positive pressuromodulation effect (i.e. endocytic) substitutes for the CD4R+ CD40LG T-cell-mediated CD40R B-cell polarization pressuromodulation effect. †, upper esebssiwaagoT $T_{Q}$ units range, 0.41-0.36. Black, CD40 at maximum cell polarization potential (CD40R+). Dark blue, CD40 at half-refractory (CD4OR \pm ). Light blue, CD40 at full-refractory (CD40R-). Thick black lined large rectangular box, extra-nodal secretory antibody phase 


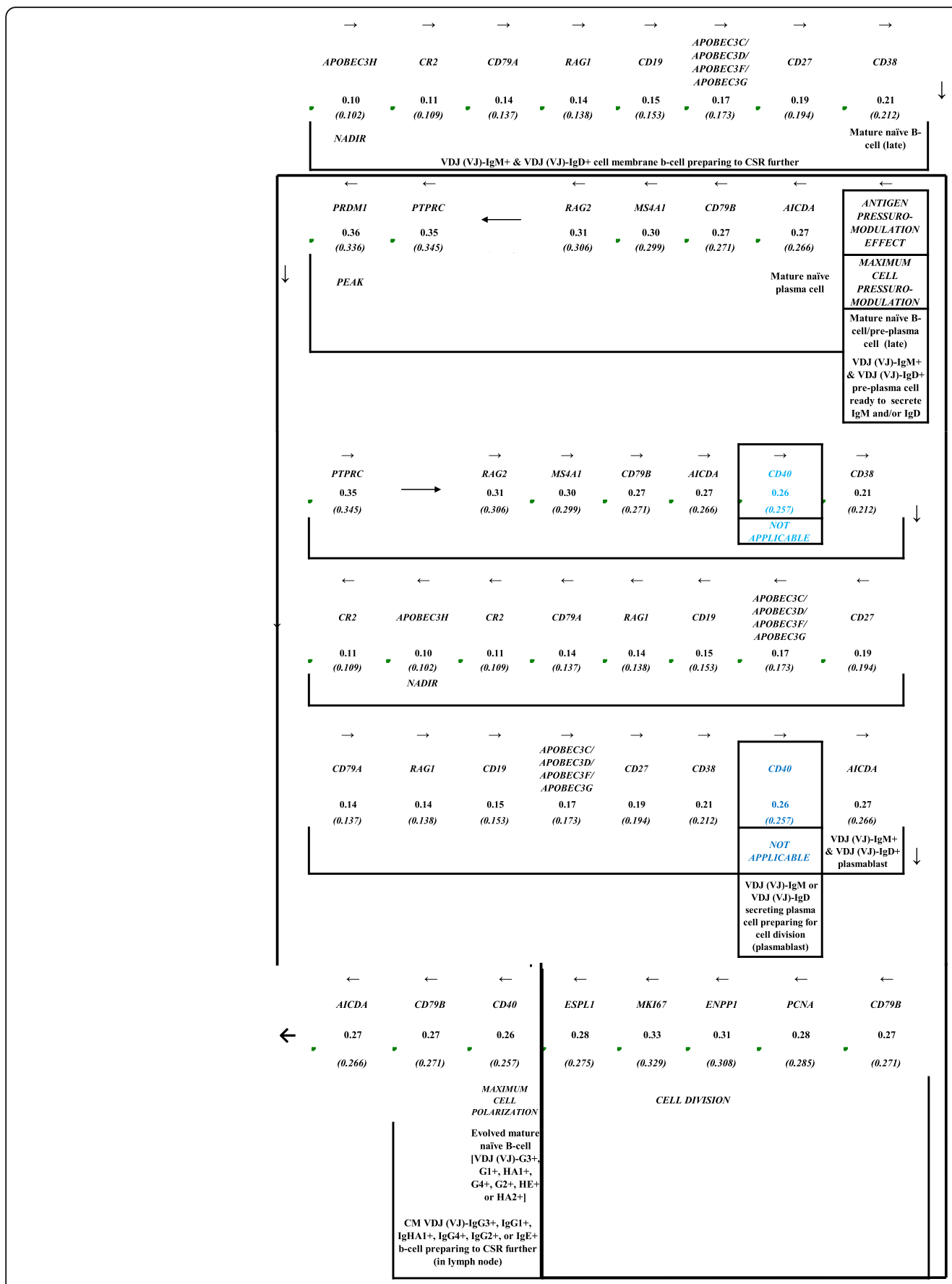

Fig. 1 Pressuromodulation map of B-cell differentiation stages. There are three completed maximal B-cell polarization periods with another to begin $(C D 40 R+)$, two half-refractory B-cell polarization periods (CD40R \pm ), and four full-refractory B-cell polarization periods (CD40R-) to the 1st generation CM VDJ (VJ)-lgG3+, lgG1+, lgHA1+, lgG4+, lgG2+ or lgE+ (excluding lgA2+) Evolved Mature naïve B-cell preparing to CSR further in the lymph node (2nd phase) after the completing the Immature B-cell phase in the myeloid bone marrow (1st phase). The antigen pressuromodulation effectmediated extra-lymph nodal long-lived B-plasma cell/plasmablast secretory antibody phase (3rd phase) takes place in the periphery/tissue nidus. Note: The classical pathway B-cell maturation pressuromodulation map is shown, however the map applies to the parallel alternate B-cell maturation pathway wherein the T-cell independent antigen-mediated toll-like receptor (TLR) positive pressuromodulation effect (i.e. endocytic) substitutes for the CD4R+ CD40LG T-cell-mediated CD40R B-cell polarization pressuromodulation effect. †, upper esebssiwaagoT $T_{Q}$ units range, 0.41-0.36. Black, CD40 at maximum cell polarization potential (CD40R+). Dark blue, CD40 at half-refractory (CD4OR \pm ). Light blue, CD40 at full-refractory (CD40R-). Thick black lined large rectangular box, extra-nodal secretory antibody phase 
Table 3 Chromosome $6(+)$ strand chromatin B-cell transcription factor adapter gene, PRDM1, esebssiwaago T, for pressuromodulation mapping of B-cell differentiation

\begin{tabular}{llllll}
\hline $\begin{array}{l}\text { Germline } \\
\text { Gene }\end{array}$ & $\begin{array}{l}\text { Germline } \\
\text { gene locus }\end{array}$ & $\begin{array}{l}\text { Ch } \\
\text { No.(Strand) }\end{array}$ & $\begin{array}{l}\text { Total no. of transcribed bases at gene } \\
\text { locus or n/a (episode category) }\end{array}$ & $\begin{array}{l}\text { Initial no. of sub-episode blocks (converted } \\
\text { final no. of sub-episode blocks, or n/a) }\end{array}$ & $\begin{array}{l}\text { Germline gene 2-digit } \\
\text { (3-digit) esebssiwaagoT, } \\
\text { or n/a }\end{array}$ \\
\hline PRDM1 & PRDM1 & $6 \mathrm{q} 21(+)$ & $23,620(2)$ & $5(\mathrm{n} / \mathrm{a})$ & $0.36(0.356)$ \\
\hline
\end{tabular}

${ }^{a}>11,864 \leq 265,005$ total transcribed bases, Episode category 2 gene; Episode category 3 gene bases, $\leq 11,864$ total transcribed bases, Episode category 3 gene

Table 4 Chromosome $6(+)$ chromatin B-cell transcription factor adapter gene, PRDM1, sequential esebssiwaagoT $T_{\mathrm{Q}} \mathrm{to}$ final 2-digit (and 3-digit) esebssiwaagoto

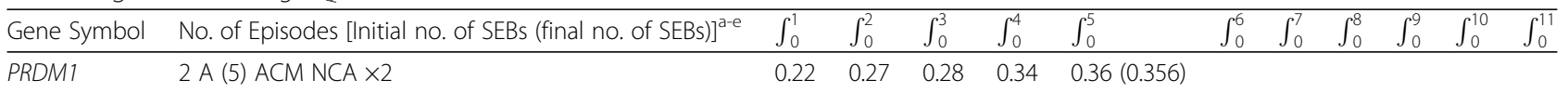

${ }^{\mathrm{a}}$ 1st episode beginning with an anisotropic sub-episode block (SEB), A, or beginning with a mesotropic SEB, M; ${ }^{b}$ non-contributory anisotropic sub-episode block (NCA); ' non-contributory single or multiple stabilizing isotropy points or reverse stabilizing isotropy point(s), NCstl; ${ }^{d}$ anisotropy converted-to-mesotropy, ACM; and indirect reverse stlsotropy and/or stlsotropy for anisotropy, stMfA, or for mesotropy, stMfM

Table 5 Chromosome $20(+)$ strand chromatin B-cell polarization receptor gene, CD40, and chromosome $1(+)$ strand chromatin B-cell polarization receptor gene, $P T P R C$, esebssiwaagoT $>$ for pressuromodulation mapping of B-cell differentiation

\begin{tabular}{llllll}
\hline $\begin{array}{l}\text { Germline } \\
\text { Gene }\end{array}$ & $\begin{array}{l}\text { Germline } \\
\text { gene locus }\end{array}$ & $\begin{array}{l}\text { Ch No. } \\
\text { (Strand) }\end{array}$ & $\begin{array}{l}\text { Total no. of transcribed bases at gene } \\
\text { locus or n/a (episode category) }\end{array}$ & $\begin{array}{l}\text { Initial no. of sub-episode blocks (converted } \\
\text { final no. of sub-episode blocks, or n/a) }\end{array}$ & $\begin{array}{l}\text { Germline gene 2-digit } \\
\text { (3-digit) } \\
\text { or n/a }\end{array}$ \\
\hline CD40 & CD40 & $20 p 13.12(+)$ & $15,922(2)$ & $5(\mathrm{n} / \mathrm{a})$ & $0.26(0.257)$ \\
PTPRC & PTPRC & $1 \mathrm{q} 31.3(+)$ & $118,806(2)$ & $5(2)$ & $0.35(0.345)$ \\
\hline
\end{tabular}

${ }^{a}>11,864 \leq 265,005$ total transcribed bases, Episode category 2 gene; Episode category 3 gene bases, $\leq 11,864$ total transcribed bases, Episode category 3 gene

Table 6 Chromosome $20(+)$ strand chromatin B-cell polarization receptor gene, CD40, and chromosome 1 (+) strand chromatin B-cell polarization receptor gene, PTPRC, sequential esebssiwaago $T_{\mathrm{Q}} \mathrm{S}$ to final 2-digit (and 3-digit) esebssiwaago $T_{\mathrm{Q}}$

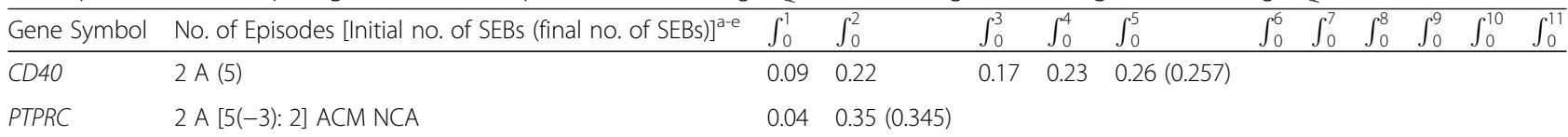

${ }^{\mathrm{a}}$ 1st episode beginning with an anisotropic sub-episode block (SEB), $\mathrm{A}$, or beginning with a mesotropic SEB, $\mathrm{M}{ }^{\mathrm{b}}$ non-contributory anisotropic sub-episode block (NCA); ${ }^{C}$ non-contributory single or multiple stabilizing isotropy points or reverse stabilizing isotropy point(s), NCstl; ${ }^{d}$ anisotropy converted-to-mesotropy, ACM; and eindirect reverse stlsotropy and/or stlsotropy for anisotropy, stMfA, or for mesotropy, stMfM

Table 7 (+) strand chromatin CD19, MSA1, CR2, CD27 and CD38 cluster of differentiation receptor gene esebssiwaagoT $S$ for pressuromodulation mapping of B-cell differentiation

\begin{tabular}{|c|c|c|c|c|c|}
\hline $\begin{array}{l}\text { Germline } \\
\text { Gene }\end{array}$ & Germline gene locus & $\begin{array}{l}\text { Ch No. } \\
\text { (Strand) }\end{array}$ & $\begin{array}{l}\text { Total no. of transcribed bases at } \\
\text { gene locus or n/a (episode } \\
\text { category) }\end{array}$ & $\begin{array}{l}\text { Initial no. of sub-episode blocks } \\
\text { (converted final no. of sub-episode } \\
\text { blocks, or n/a) }\end{array}$ & $\begin{array}{l}\text { Germline gene 2-digit } \\
\text { (3-digit) esebssiwaagot } T_{Q} \\
\text { or } \mathrm{n} / \mathrm{a}\end{array}$ \\
\hline CD19 & CD19/Inc-CD19-1 & 16p11.2(+) & $8755(3)$ & $7(5)$ & $0.15(0.153)$ \\
\hline MS4A1 & MS4A1/Inc-MS4A18-1 & $11 q 12.2(+)$ & $20,928(2)$ & $5(3)$ & $0.30(0.299)$ \\
\hline CR2 & LNC-CD55-2/CR2 & $1 \mathrm{q} 32.2(+)$ & $76,431(2)$ & $5(n / a)$ & $0.11(0.109)$ \\
\hline CD27 & $\begin{array}{l}\text { SRP14P1/Inc-PLEKHG6-1/ } \\
\text { CD27/TAPBPL/Inc-PLEKHG6-4 }\end{array}$ & $12 \mathrm{p} 13.31(+)$ & $28,585(2)$ & $5(n / a)$ & 0.19 (0.194) \\
\hline CD38 & CD38 & $4 p 15.32(+)$ & 74.956 (2) & 5 (n/a) & $0.21(0.212)$ \\
\hline
\end{tabular}

$a_{>} 11,864 \leq 265,005$ total transcribed bases, Episode category 2 gene; Episode category 3 gene bases, $\leq 11,864$ total transcribed bases, Episode category 3 gene 
Table 8 (+) strand chromatin CD19, MSA1, CR2, CD27 and CD38 cluster of differentiation receptor gene sequential esebssiwaagoT $\mathrm{S}$ to final 2-digit (and 3-digit) esebssiwaagot $T_{\mathrm{Q}}$

\begin{tabular}{|c|c|c|c|c|c|c|}
\hline Gene Symbol & No. of Episodes [Initial no. of SEBs (final no. of SEBs)] ${ }^{\text {a-e }}$ & $\int_{0}^{1}$ & $\int_{0}^{2}$ & $\int_{0}^{3}$ & $\int_{0}^{4}$ & $\begin{array}{llllll}\int_{0}^{6} & \int_{0}^{7} & \int_{0}^{8} & \int_{0}^{9} & \int_{0}^{10} & \int_{0}^{11} \\
\end{array}$ \\
\hline CD19 & 3 M [7(-2): 5] NCA NCstl & 0.48 & 0.30 & 0.27 & 0.15 & $0.15(0.153)$ \\
\hline MS4A1 & $2 \mathrm{~A}[5(-2): 3] \mathrm{NCA}$ & 0.03 & 0.35 & $0.30(0.299)$ & & \\
\hline CR2 & $2 \mathrm{~A}(5)$ & 0.14 & 0.16 & 0.06 & 0.10 & $0.11(0.109)$ \\
\hline CD27 & $2 M(5) N C A \times 2$ & 0.47 & 0.17 & 0.16 & 0.19 & $0.19(0.194)$ \\
\hline CD38 & $2 \mathrm{~A}(5) \mathrm{NCA}$ & 0.12 & 0.16 & 0.17 & 0.19 & $0.21(0.212)$ \\
\hline
\end{tabular}

${ }^{a}$ 1st episode beginning with an anisotropic sub-episode block (SEB), A, or beginning with a mesotropic SEB, M; ${ }^{b}$ non-contributory anisotropic sub-episode block (NCA); ${ }^{c}$ non-contributory single or multiple stabilizing isotropy points or reverse stabilizing isotropy point(s), NCstl; ${ }^{d}$ anisotropy converted-to-mesotropy, $A C M$; and indirect reverse stlsotropy and/or stlsotropy for anisotropy, stMfA, or for mesotropy, stMfM

Table 9 Chromosome 17 (-) strand chromatin cluster of differentiation pre-B-cell receptor gene, CD79B, and chromosome 19 (+) strand chromatin pre-B-cell receptor gene, CD79A, esebssiwaagoT for pressuromodulation mapping of B-cell differentiation

\begin{tabular}{llllll}
\hline $\begin{array}{l}\text { Germline } \\
\text { Gene }\end{array}$ & $\begin{array}{l}\text { Germline } \\
\text { gene locus }\end{array}$ & $\begin{array}{l}\text { Ch No. } \\
\text { (Strand) }\end{array}$ & $\begin{array}{l}\text { Total no. of transcribed bases at gene } \\
\text { locus or n/a (episode category) })^{1}\end{array}$ & $\begin{array}{l}\text { Initial no. of sub-episode blocks (converted } \\
\text { final no. of sub-episode blocks, or n/a) }\end{array}$ & $\begin{array}{l}\text { Germline gene 2-digit } \\
\text { (3-digit) esebssiwaagot } \\
\text { or n/a }\end{array}$ \\
\hline CD79B & CD79B & $17 q 23.3(-)$ & $3617(3)$ & $7(\mathrm{n} / \mathrm{a})$ & $0.27(0.271)$ \\
CD79A & CD79A & $19 q 13.2(+)$ & $4253(3)$ & $7(\mathrm{n} / \mathrm{a})$ & $0.14(0.137)$ \\
\hline
\end{tabular}

${ }^{a}>11,864 \leq 265,005$ total transcribed bases, Episode category 2 gene; Episode category 3 gene bases, $\leq 11,864$ total transcribed bases, Episode category 3 gene

Table 10 Chromosome 17 (-) strand chromatin cluster of differentiation pre-B-cell receptor gene, CD79B, and chromosome 19 (+) strand chromatin pre-B-cell receptor gene, CD79A, sequential esebssiwaagoT $T_{\mathrm{O}}$ to final 2-digit (and 3-digit) esebssiwaagoT

\begin{tabular}{|c|c|c|c|c|c|c|c|c|c|}
\hline Gene Symbol & No. of Episodes [Initial no. of SEBs (final no. of SEBs)] ${ }^{\text {a-e }}$ & $\int_{0}^{1}$ & $\int_{0}^{2}$ & $\int_{0}^{3}$ & $\int_{0}^{4}$ & $\int_{0}^{5}$ & $\int_{0}^{6}$ & $\int_{0}^{7}$ & $\int_{0}^{8} \int_{0}^{9}$ \\
\hline CD79B & $3 \mathrm{M}(7)$ & 0.53 & 0.21 & 0.37 & 0.40 & 0.36 & 0.32 & $0.27(0.271)$ & \\
\hline CD79A & $3 \mathrm{M}(7) \mathrm{ACM} N C A$ & 0.52 & 0.25 & 0.23 & 0.21 & 0.23 & 0.13 & $0.14(0.137)$ & \\
\hline
\end{tabular}

${ }^{a}$ 1st episode beginning with an anisotropic sub-episode block (SEB), A, or beginning with a mesotropic SEB, $\mathrm{M}^{\mathrm{b}}{ }^{\mathrm{b}}$ non-contributory anisotropic sub-episode block (NCA); ${ }^{C}$ non-contributory single or multiple stabilizing isotropy points or reverse stabilizing isotropy point(s), $\mathrm{NCstl}$; ${ }^{d}$ anisotropy converted-to-mesotropy, ACM; and indirect reverse stlsotropy and/or stlsotropy for anisotropy, stMfA, or for mesotropy, stMfM

Table 11 Chromosome 11 (-) strand chromatin VDJ recombinase gene, RAG2, and (+) strand chromatin VDJ recombinase gene, RAG1, esebssiwaagoT $\mathrm{Q}$ for pressuromodulation mapping of B-cell differentiation

\begin{tabular}{llllll}
\hline $\begin{array}{l}\text { Germline } \\
\text { Gene }\end{array}$ & Germline gene locus & $\begin{array}{l}\text { Ch No. } \\
\text { (Strand) }\end{array}$ & $\begin{array}{l}\text { Total no. of transcribed bases } \\
\text { at gene locus or n/a (episode } \\
\text { category) }\end{array}$ & $\begin{array}{l}\text { Initial no. of sub-episode blocks } \\
\text { (converted final no. of sub-episode } \\
\text { blocks, or n/a) }\end{array}$ & $\begin{array}{l}\text { Germline gene 2-digit } \\
\text { (3-digit) esebssiwaagot } \\
\text { or n/a }\end{array}$ \\
\hline RAG2 & $\begin{array}{l}\text { Inc-RAG2-2/RAG2/ } \\
\text { GC11M036597/Inc-RAG2-1 }\end{array}$ & $111 \mathrm{p} 12(-)$ & $46,970(2)$ & $5(4)$ & $0.31(0.306)$ \\
RAG1 & $\begin{array}{l}\text { GC11P036511,12/ENSG00000280331/ } \\
\text { RAG1/GC11P036554/ } \\
\text { GC11P036555/Inc-RAG1-1 }\end{array}$ & $11 \mathrm{p} 12(+)$ & $82,787(2)$ & $5(6)$ & $0.14(0.139)$ \\
& & & & \\
\hline
\end{tabular}

$a_{>} 11,864 \leq 265,005$ total transcribed bases, Episode category 2 gene; Episode category 3 gene bases, $\leq 11,864$ total transcribed bases, Episode category 3 gene 
Table 12 Chromosome 11 (-) strand chromatin VDJ recombinase gene, RAG2, and (+) strand chromatin VDJ recombinase gene, $R A G 1$, sequential esebssiwaago $T_{\mathrm{Q}} \mathrm{S}$ to final 2-digit (and 3-digit) esebssiwaago $T_{\mathrm{Q}}$

\begin{tabular}{|c|c|c|c|c|c|c|c|c|}
\hline Gene Symbol & No. of Episodes [Initial no. of SEBs (final no. of SEBs)] $]^{\text {a-e }}$ & $\int_{0}^{1}$ & $\int_{0}^{2}$ & $\int_{0}^{3}$ & $\int_{0}^{4}$ & $\int_{0}^{5}$ & $\int_{0}^{6}$ & $\int_{0}^{7} \quad \int_{0}^{8} \quad \int_{0}^{9} \quad \int_{0}^{10} \int_{0}^{11}$ \\
\hline RAG2 & $2 \mathrm{M}[5(-1): 4] \mathrm{NCA} \times 2 \mathrm{NCstl}$ & 0.58 & 0.29 & 0.33 & $0.31(0.306)$ & & & \\
\hline RAG1 & $2 \mathrm{~A}\left[5(+1): 6^{*}\right] \mathrm{ACM}^{*} \mathrm{NCA}$ & 0.12 & 0.14 & 0.14 & 0.15 & 0.13 & $0.14(0.139)$ & \\
\hline
\end{tabular}

${ }^{a}$ 1st episode beginning with an anisotropic sub-episode block (SEB), A, or beginning with a mesotropic SEB, $\mathrm{M}^{\mathrm{b}}{ }^{\mathrm{b}}$ non-contributory anisotropic sub-episode block (NCA); ${ }^{c}$ non-contributory single or multiple stabilizing isotropy points or reverse stabilizing isotropy point(s), $\mathrm{NCstl;}{ }^{d}$ anisotropyconverted-to-mesotropy, ACM; and eindirect reverse stlsotropy and/or stlsotropy for anisotropy, stMfA, or for mesotropy, stMfM. ${ }^{*} \mathrm{ACM}$ of SEB no. 5 due to stabilizing isotropy preceding ending confirmation mesotropic SEB (no. 6) which sums into SEB no. 5 (final SEB count is 6*)

CSR and somatic hypermutation enzyme genes, $A I C D A$, and $A P O B E C 3 A$ through $A P O B E C 3 H$

$A I C D A$ is is a 3 episode, 7 initial and final SEB gene that begins with a mesotropic SEB. AICDA has two instances of anisotropy converted-to-mesotropy. AICDA is a $3 \mathrm{M}$ (7) $\mathrm{ACM} \times 2$ gene with a final esebssiwaago $T_{\mathrm{Q}}$ of .27 (0.266).

$A P O B E C 3 A / A P O B E C 3 B$ is a 2 episode, 5 initial and final SEB gene that begins with a mesotropic SEB. APO$B E C 3 / A P O B E C 3 B$ has one instance of indirect stIsotropy for anisotropy, and one instance of non-contributory anisotropy. $A P O B E C 3 / A P O B E C 3 B$ is a $2 \mathrm{M}$ (5) stIMfA NCA gene with a final esebssiwaago $T_{\mathrm{Q}}$ of $0.22(0.216)$.

APOBEC $3 C / A P O B E C 3 D / A P O B E C 3 F / A P O B E C 3 G$ is a 2 episode, 5 initial SEB and final SEB gene that begins with an anisotropic SEB. APOBEC3C/APOBEC3D/ $A P O B E C 3 F / A P O B E C 3 G$ has one instance of noncontributory anisotropy. APOBEC3C/APOBEC $3 D / A P O-$ $B E C 3 F / A P O B E C 3 G$ is a 2 A (5) NCA gene with a final esebssiwaago $T_{\mathrm{Q}}$ of 0.17 (0.173).

APOBEC $3 H$ is a 3 episode, 7 initial SEB and 11 final SEB gene that begins with a mesotropic SEB. APOBEC $3 H$ has two instances of anisotropy converted-to-mesotropy, and one instance of non-contributory anisotropy. $A P O B E C 3 H$ is a $3 \mathrm{M}[7(+4): 11] \mathrm{ACM} \times 2 \mathrm{NCA}$ gene with a final esebssiwaago $T_{\mathrm{Q}}$ of 0.10 (0.102) (Table 13, Table 14; Fig. 1).
Cell proliferation marker genes, MKI67, ENPP1, PCNA and ESPL1

MKI67 is a 2 episode, 5 initial SEB and final SEB gene that begins with an mesotropic SEB. MKI67 is a $2 \mathrm{M}$ (5) gene with a final esebssiwaago $T_{\mathrm{Q}}$ of 0.33 (0.329).

ENPP1 is a 2 episode, 5 initial and final SEB gene that begins with an anisotropic SEB. ENPP1 has two instances of anisotropy converted-to-mesotropy. ENPP1 is a $2 \mathrm{~A}$ (5) $\mathrm{ACM} \times 2$ gene with a final esebssiwaago $T_{\mathrm{Q}}$ of $0.31(0.308)$.

$P C N A$ is a 3 episode, 7 initial SEB and 4 final SEB gene that begins with an anisotropic SEB. PCNA has two instances of non-contributory anisotropy. PCNA is a $3 \mathrm{~A}$ [7(-3): 4] $\mathrm{NCA} \times 2$ gene with a final esebssiwaago $T_{\mathrm{Q}}$ of $0.28(0.285)$.

ESPL1 is a 2 episode, 5 initial and final SEB gene that begins with a mesotropic SEB. ESPL1 has one instance of non-contributory stIsotropy. ESPL1 is a $2 \mathrm{M}$ (5) NCstI gene with a final esebssiwaago $T_{\mathrm{Q}}$ of $0.28(0.275)$ (Table 15 , Table 16; Fig. 1).

\section{Discussion}

Methodological considerations in determination of gene esebssiwaago $T_{\mathrm{Q}} \mathrm{s}$

Since the validation of the $5^{\prime}->3^{\prime}$ esebssiwaago $T_{Q}$, no changes to the methodology have been made [2, 3]; however, some new acronyms have been utilized to indicate single or multiple occurrences within a single sub-episode

Table 13 Chromosome 12 (-) strand chromatin consensus sequence recognition (CSR) and somatic hypermutation (SHM) enzyme gene, AICDA, esebssiwaagoT, and chromosome $22(+)$ strand CSR and SHM genes, APOBEC3A through APOBEC $3 H_{\text {, esebssiwaagoT }} \mathrm{S}$ for pressuromodulation mapping of B-cell differentiation

\begin{tabular}{|c|c|c|c|c|c|}
\hline Germline Gene & $\begin{array}{l}\text { Germline gene } \\
\text { locus }\end{array}$ & $\begin{array}{l}\text { Ch No. } \\
\text { (Strand) }\end{array}$ & $\begin{array}{l}\text { Total no. of transcribed bases } \\
\text { at gene locus or n/a (episode } \\
\text { category) }\end{array}$ & $\begin{array}{l}\text { Initial no. of sub-episode blocks } \\
\text { (converted final no. of sub-episode } \\
\text { blocks, or n/a) }\end{array}$ & $\begin{array}{l}\text { Germline gene 2-digit } \\
\text { (3-digit) esebssiwaagot } \\
\text { or } \mathrm{n} / \mathrm{a}\end{array}$ \\
\hline AICDA & AICDA & 12 p31.2 (-) & $10.723(3)$ & 7 (n/a) & $0.27(0.266)$ \\
\hline $\begin{array}{l}A P O B E C 3 A \\
A P O B E C 3 B\end{array}$ & $\begin{array}{l}A P O B E C 3 A \\
A P O B E C 3 B\end{array}$ & $22 q 13.1(+)$ & $40,064(2)$ & $5(n / a)$ & $0.22(0.216)$ \\
\hline $\begin{array}{l}\text { APOBEC } 3 C / \\
\text { APOBEC } 3 D / \\
A P O B E C 3 F / \\
\text { APOBEC } 3 G\end{array}$ & $\begin{array}{l}\text { APOBEC3C/ } \\
\text { APOBEC3D/ } \\
\text { APOBEC3F/ } \\
\text { APOBEC3G }\end{array}$ & $22 q 13.1(+)$ & $73,661(2)$ & 5 (n/a) & $0.17(0.173)$ \\
\hline APOBEC $3 \mathrm{H}$ & APOBEC $3 \mathrm{H}$ & $22 q 13.1(+)$ & $6845(3)$ & $7(11)$ & $0.10(0.102)$ \\
\hline
\end{tabular}

${ }^{a}>11,864 \leq 265,005$ total transcribed bases, Episode category 2 gene; Episode category 3 gene bases, $\leq 11,864$ total transcribed bases, Episode category 3 gene 
Table 14 Chromosome $12(-)$ strand chromatin consensus sequence recognition (CSR) and somatic hypermutation (SHM) enzyme gene, AICDA, and chromosome $22(+)$ strand CSR and SHM gene, APOBEC3A through APOBEC3H, sequential esebssiwaagoT $T_{\mathrm{Q}}$ to final 2-digit (and 3-Q digit) esebssiwaago $T_{\mathrm{Q}}$

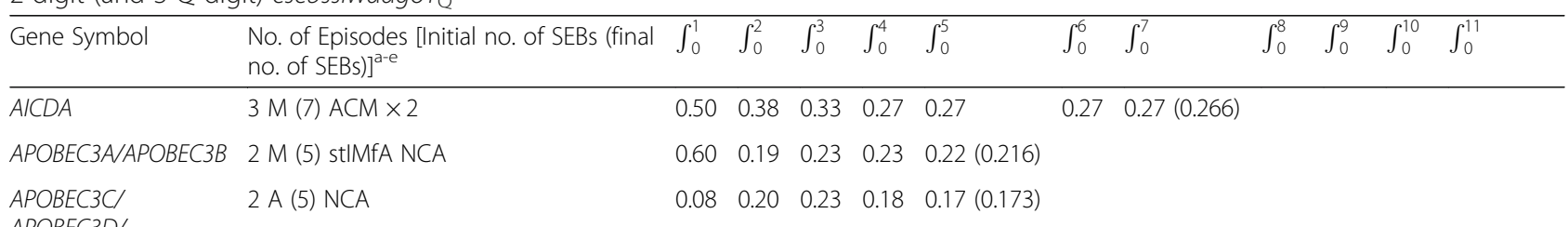

$A P O B E C 3 D /$

APOBEC3F/

APOBEC3G

APOBEC $3 H$

$3 \mathrm{M}[7(+4): 11] \mathrm{ACM} \times 2 \mathrm{NCA}$

$\begin{array}{lllll}0.71 & 0.37 & 0.32 & 0.08 & 0.07\end{array}$

$0.08 \quad 0.09$

$0.11 \quad 0.11 \quad 0.10 \quad 0.10(0.102)$

${ }^{\mathrm{a}} 1$ st episode beginning with an anisotropic sub-episode block (SEB), A, or beginning with a mesotropic SEB, M; ${ }^{b}$ non-contributory anisotropic sub-episode block (NCA); ${ }^{c}$ non-contributory single or multiple stabilizing isotropy points or reverse stabilizing isotropy point(s), NCstl; ${ }^{d}$ anisotropy converted-to-mesotropy, ACM; and eindirect reverse stlsotropy and/or stlsotropy for anisotropy, stMfA, or for mesotropy, stMfM

block (SEB), where the phrase, one stance, refers to single or multiple occurrences within a single SEB, while the phrase two instances refers to the same in 2 different SEBs.

The new acronyms include: (1) NCA to indicate a non-contributory anisotropic sub-episode block (SEB) due to the presence of reverse anisotropy of equal or greater magnitude; (2) NCstI to indicate single or multiple non-contributory stabilizing isotropy point(s) or reverse stabilizing isotropy point(s) within a SEB; (3) ACM to indicate anisotropy converted-to-mesotropy due to direct reverse stIsotropy $\left(3^{\prime} \rightarrow 5^{\prime}\right.$ direction on the same strand) and/or stIsotropy $\left(5^{\prime} \rightarrow 3^{\prime}\right.$ direction on the same strand) preceding a single anisotropic $\operatorname{prp}_{\mathrm{Q}}$ point of a single or multiple point-containing anisotropic SEB; and (4) stMfA or stMfM to indicate the presence of indirect reverse stIsotropy and/or stIsotropy that first converts a single mesotropic point into a stIsotropy point that after a further 0.5-factor adjustment (half-magnitude adjustment) may or may not convert the next single anisotropic point (stMfA) into a mesotropic point, or the same that may theoretically convert the next single mesotropic point to another stIsotropy point (encountered $0 \%$ of the time thus far) or may not convert the next single mesotropic point to another stIsotropy point (encountered $100 \%$ of the time thus far).

\section{Determination of cell differentiation stage in gene esebssiwaago $T_{\mathrm{Q}}$-based $\mathrm{B}$-cell differentiation pressuromodulation mapping}

Cell differentiation stages have been determined on the basis of overexpressed and under-expressed B-cell markers taking into consideration changes in B-cell morphology [4] in reference to the three periods of Bcell polarization (Fig. 1. Pressuromodulation map of Bcell differentiation stages).

The Early pro-B cell stage begins with the overexpression of PRDM1 (PRDM1 gene esebssiwaagoT $T_{Q}$ : 0.356) and lasts into the $1^{\text {st }}$ maximum CD40LG-CD40Rmediated B-cell polarization period (CD40R+) (Fig. 1).

The Large pre-B cell stage with B-cell morphology of the same is before the $1^{\text {st }}$ half-refractory CD40LG-CD40Rmediated B-cell polarization period until the $1^{\text {st }}$ B-cell division $(\mathrm{CD} 40 \mathrm{R}+)$, and the Small pre-B-cell stage with Bcell morphology of the same begins after the $1^{\text {st }}$ halfrefractory CD40LG-CD40R-mediated B-cell polarization period following the $1^{\text {st }}$ B-cell division (CD40R \pm ) (Fig. 1).

The Immature B-cell stage begin after the $3^{\text {rd }}$ maximum CD40LG-CD40R mediated B-cell polarization period $(\mathrm{CD} 40 \mathrm{R}+)$ when CD20R is over-expressed (MS4A1 gene esebssiwaago $\left.T_{Q}: 0.299\right)$ and $C D 38 \mathrm{R}$ is under-expressed (CD38 gene esebssiwaago $T_{Q}: 0.212$ ), and lasts into the

Table $15(-)$ and (+) strand chromatin MKI67, ENPP1, PCNA and ESPL1 cell proliferation marker gene esebssiwaagoT $\mathrm{Q}$ for pressuromodulation mapping

\begin{tabular}{|c|c|c|c|c|c|}
\hline $\begin{array}{l}\text { Germline } \\
\text { Gene }\end{array}$ & $\begin{array}{l}\text { Germline } \\
\text { gene locus }\end{array}$ & $\begin{array}{l}\text { Ch No. } \\
\text { (Strand) }\end{array}$ & $\begin{array}{l}\text { Total no. of transcribed bases at gene } \\
\text { locus or n/a (episode category) }\end{array}$ & $\begin{array}{l}\text { Initial no. of sub-episode blocks (converted } \\
\text { final no. of sub-episode blocks, or n/a) }\end{array}$ & $\begin{array}{l}\text { Germline gene 2-digit } \\
\text { (3-digit) esebssiwaagot } \\
\text { or } \mathrm{n} / \mathrm{a}\end{array}$ \\
\hline MKI67 & $\begin{array}{l}\text { Inc-C10orf90-4/ } \\
\text { MKI67 }\end{array}$ & 10q26.2 (-) & 33,958 (2) & 5 (n/a) & $0.33(0.329)$ \\
\hline ENPP1 & ENPP1 & $6 \mathrm{q} 23.2(+)$ & $87,140(2)$ & 5 (n/a) & $0.31(0.308)$ \\
\hline PCNA & PCNA & 20p12.3 (-) & $11,674(3)$ & $7(4)$ & $0.28(0.285)$ \\
\hline ESPL1 & ESPL1 & $12 q 13.13(+)$ & $25,378(2)$ & 5 (n/a) & $0.28(0.275)$ \\
\hline
\end{tabular}

${ }^{a}>11,864 \leq 265,005$ total transcribed bases, Episode category 2 gene; Episode category 3 gene bases, $\leq 11,864$ total transcribed bases, Episode category 3 gene 
Table $16(-)$ and (+) strand chromatin MKI67, ENPP1, PCNA and ESPL1 cell proliferation marker gene sequential esebssiwaagoT $\mathrm{Q}$ to final 2-digit (and 3-digit) esebssiwaagotQ

\begin{tabular}{lllllllllll}
\hline Gene Symbol & No. of Episodes [Initial no. of SEBs (final no. of SEBs)] $]^{\mathrm{a}-\mathrm{e}}$ & $\int_{0}^{1}$ & $\int_{0}^{2}$ & $\int_{0}^{3}$ & $\int_{0}^{4}$ & $\int_{0}^{5}$ & $\int_{0}^{6} \int_{0}^{7} \int_{0}^{8} \int_{0}^{9} \int_{0}^{10} \int_{0}^{11}$ \\
\hline MKI67 & $2 \mathrm{M} \mathrm{(5)}$ & 0.28 & 0.26 & 0.25 & 0.24 & $0.33(0.329)$ & & & \\
ENPP1 & 2 A (5) ACM $\times 2$ & 0.05 & 0.36 & 0.36 & 0.31 & $0.31(0.308)$ & \\
PCNA & 3 A [7(-3): 4] NCA ×2 & 0.46 & 0.20 & 0.32 & $0.28(0.285)$ & & & \\
ESPL1 & 2 M (5) NCstl & 0.27 & 0.19 & 0.29 & 0.26 & $0.28(0.275)$ &
\end{tabular}

${ }^{a}$ 1st episode beginning with an anisotropic sub-episode block (SEB), A, or beginning with a mesotropic SEB, M; ${ }^{b}$ non-contributory anisotropic sub-episode block (NCA); ${ }^{C}$ non-contributory single or multiple stabilizing isotropy points or reverse stabilizing isotropy point(s), ${ }^{N C s t l ;}{ }^{d}$ anisotropy converted-to-mesotropy, $A C M$; and

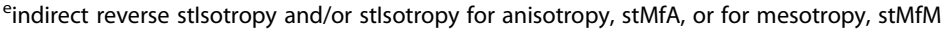

$2^{\text {nd }}$ half-refractory CD40LG-CD40R mediated B-cell polarization period until the $2^{\text {nd }}$ B-cell division $(C D 40 R \pm)$ (Fig. 1).

The Mature (naïve) B-cell-stage begins after the $2^{\text {nd }}$ half-refractory CD40LG-CD40R mediated B-cell polarization period following the $2^{\text {nd }} \mathrm{B}$-cell division $(\mathrm{CD} 40 \mathrm{R} \pm)$, and lasts into the $4^{\text {th }}$ fully-refractory CD40LG-CD40R mediated B-cell polarization period (CD40R-) when CD21R is over-expressed (CR2 gene esebssiwaago $T_{Q}$ : 0.109) during the nadir (Fig. 1).

Supra-pressuromodulated gene $C D 34$ expression at an esebssiwaago $T_{Q}$ of 0.648 is consistent with pluripotent cells being the most pressuromodulated cells

Pluripotent stem cells are maintained at the cortical subcortical cavern interface of the myeloid bone marrow due to synergistic cell membrane $(\mathrm{CM})$ pressuromodulation. These cells overexpress CD34 (esebssiwaago $T_{\mathrm{Q}}$ : 0.648), which is consistent with the over-pressuromodulated state of pluripotency.

For the subset of CD34R+ pluripotent stem cells that divide to mature further in the sub-cortical marrow caverns to express antagonist transcription factor gene PRDM1, it is the overexpression of PRDM1 (esebssiwaa$\left.g o T_{\mathrm{Q}}: 0.356\right)$ and then $C D 40$ and $C D 40 \mathrm{R}$ that drives the cell differentiation process down the B-cell lineage path and starts the $\mathrm{V}(\mathrm{D}) \mathrm{J}$ gene recombination process [20]; whereas, for the subset of CD34R+ stem cells that divide to mature further in the sub-cortical marrow caverns to express transcription factor gene GATA1, it is the overexpression of GATA1 and then the transferrin receptor I gene, TFRC and its endocytic receptor TFR (CD71) that drives the hemopoietic differentiation process down the erythroid lineage path to the anucleated erythrocyte for example [21, 22].

\section{Supra-pressuromodulated transcription factor} antagonist gene PRDM1 with an esebssiwaago $T_{Q}$ of 0.356 and B-cell polarization gene PTPRC with an esebssiwaago $T_{Q}$ of 0.345 consistent with a PTPRC PRDM1 expression-potentiating effect

Both the master transcription factor antagonist gene, PRDM1, and B-cell polarization receptor gene, PTPRC, are expressed within 0.011 esebssiwaago $T_{\mathrm{Q}}$ units of each other, the former at 0.356 and the later at 0.345 ; as such, PTPRC expression potentiates the duration of PRDM1 expression, which results in maximal PRDM1 expression, the transcription factor antagonist (TF ANT) of $C-M Y C$.

The PTPRC, protein product, CD45R, binds to its dendritic cell $\mathrm{CM}$ overexpressed receptor ligand on a morphologically sprouted cell type, which polarizes less. Thus, the CD45R-mediated B-cell polarization effect will be much lesser in magnitude than that of the CD4R+ T-cell CD40LG-to-B-cell CD40R-mediated B-cell polarization effect; however, sufficient enough for maximizing PRDM1 gene expression. Following sustained PRDM1 expression and PRDM1 repression of $C-M Y C$, B-cell intracellular pressure either: (1) decreases at a slower rate to a pressure of 0.26 (0.257) esebssiwaago $T_{\mathrm{Q}}$ units that results in maximal CD40 expression (CD40R+) and in a maximal polarization period (Fig. 1); or (2) decreases at a faster rate to below 0.26 units that results in $C D 40$ non-expression and a full refractory polarization period (CD40R-) (Fig. 1).

Therefore, the maximal CD40 expression $(\mathrm{CD} 40 \mathrm{R}+)$ period is a function of preceding PRDM1 expression only, while the CD40 non-expression period (CD40R-) is a function of preceeding CD40 and PRDM1 expression in series [20].

\section{Supra-pressuromodulated gene CD40 expressed at an} esebssiwaago $T_{Q}$ of 0.257 is the master regulator of $\mathrm{B}$-cell polarization during maximum polarization and half-refractory periods

There are three maximal B-cell polarization periods $(\mathrm{CD} 40 \mathrm{R}+)$, there are two half-refractory B-cell polarization periods $(\mathrm{CD} 40 \mathrm{R} \pm)$, and four full-refractory $\mathrm{B}$-cell polarization periods (CD40R-) to the Mature naive B-cell cell membrane IgM and IgD antibody expression stage, the IgM+/IgD+ B-cell (Fig. 1).

The expression of B-cell CD40 and CD40R at 0.257 esebssiwaago $T_{\mathrm{Q}}$ units results in the CD40LG-CD40Rmediated B-cell polarization $(\mathrm{CD} 40 \mathrm{R}+)$ and is of sufficient magnitude to temporarily increase 
intracellular pressure upto 0.41 esebssiwaago $T_{\mathrm{Q}}$ units during B-cell differentiation in the myeloid marrow (phase 1) and the lymph node (phase 2) until B-cell to plasma cell transformation. As mitochondrial content is lowest during earliest stages of B-cell development, initially there are two sequential periods of maximal CD40LG-CD40R-mediated B-cell polarization $(\mathrm{CD} 40 \mathrm{R}+)$. And, after each maximal B-cell polarization period, the rate of decrease in B-cell intracellular pressure is sufficient to decrease the intracellular pressure below 0.257 esebssiwaago $T_{\mathrm{Q}}$ units to result in a full refractory period (CD40R-) when the B-cell enters its $G_{0}$ phase (Fig. 1).

By the end of the $2^{\text {nd }}$ full refractory period (CD40R-), the B-cell mitochondrial content has increased and stabilized within a constant interval in which it then fluctuates in the Yang Yin, while the B-cell has matured to the point of a mid-to-late Large pre-B cell. The $1^{\text {st }}$ halfrefractory period follows (CD40R \pm ), during which a Bcell divides (Fig. 1).

The existence of two successive initial periods of maximal CD40R polarization is a function of B-cell mitochondrial content.

\section{Infra-pressuromodulated cluster of differentiation receptor genes $C D 19, C R 2, C D 27$ and $C D 38$ between an esebssiwaago $T_{Q}$ range of $0.109-0.194$ are $G_{0}$ phase expressed genes}

The $G_{0}$ phase B-cell cluster of differentiation marker genes are $C D 27$ (esebssiwaago $T_{\mathrm{Q}}:$ 0.194), CD19 (B4) (esebssiwaago $\left.T_{\mathrm{Q}}: 0.153\right)$, and $C R 2$ (CD21) (esebssiwaa$\left.g o T_{\mathrm{Q}}: 0.109\right)$ appear to be sequentially expressed in descending then ascending order throughout B-cell maturation. MS4A1 (CD20) (esebssiwaagoT $T_{\mathrm{Q}}$ of 0.299 ) is first expressed during the $1^{\text {st }}$ maximal B-cell polarization period $(\mathrm{CD} 40 \mathrm{R}+)$ and thereafter during each maximal B-cell polarization period; while, the rest of the CD marker genes are expressed during the peri-nadir after each full-refractory period into each maximal B-cell polarization period and into each half-refractory period, when the B-cell enters its $G_{0}$ phase.

As per the classical B-cell maturation pathway (T-cell mediated pressuromodulator antigen pathway), the B-cell cluster of differentiation marker genes are expressed sequentially during the first two phases of B-cell differentiation. They are expressed through the myeloid marrow phase, during the Large pre-B cell, Small pre-B-cell and Immature B-cell stages to the point of a CM IgM+ and a Allele 2 (IGHD) V(D)J stepcompleted early Immature B-cell (Fig. 1). And then, they are expressed through the node germinal center phase, during the Mature naïe B-cell and Evolved Mature naïve B-cell stages to the point of $\mathrm{CM} \operatorname{IgM}+\operatorname{IgD}+$ Mature naïve $\mathrm{B}$-cell after homologous recombination or to the point of a CM IgM+ IgM+ Mature naïve B-cell after initial allelic exclusion $\rightarrow$ [secretory $\operatorname{IgM}+( \pm \operatorname{IgD}+)$ or IgM+/IgM+ Mature B-pre-plasma/plasma cell and lymph node exit in early live infection (IgM response) when peak concentrations of systemically circulating antigenic pressuromodulators are present (Fig. 1)] $\rightarrow$ primary isotype switched $\mathrm{Ig}_{-}+/ \mathrm{Ig}_{-}+1$ st generation Evolved Mature naïve B-cell for example $\rightarrow$ [secretory IgG_+/IgG_ + and lymph node exit in either (1) late live infection (IgG response) when lower concentrations of systemic antigenic pressuromodulators are present, or (2) in attenuated strain/type vaccination [23] or nonpathogenic antigen vaccination when local concentrations of antigenic pressuromodulators are present (Fig. 1)].

Supra-pressuromodulated B-cell receptor gene $C D 79 B$ with an esebssiwaago $T_{\mathrm{Q}}$ of $\mathbf{0 . 2 7 1}$ and infra- pressuromodulated gene $C D 79 A$ with an esebssiwaago $T_{Q}$ of 0.137 are unimodally expressed during the secretory antibody phase

Both CD79B (B-cell ARC-AP $\beta$ ) and CD79A (B-cell $\mathrm{ARC}-\mathrm{AP} \alpha)$ are required for stably anchored cell membrane antibody. The $\alpha$ and the $\beta$ BCR subunit genes are expressed temporarily in series in between the full refractory and maximum polarization periods at intracellular pressures of 0.137 and 0.271 units, respectively (Fig. 1). This is the case during the first two phases when CD4R+ T-cell-mediated B-cell polarization and the $C D 40$ (Yin) $\rightarrow$ PRDM1 (Yang) $\rightarrow 0.10$ to 0.12 units nadir effect is driving the B-cell differentiation process, as Bcell pressure oscillates in between the peak and the nadir.

During the third phase, the B-cell-to-pre-plasma/ plasma cell transformation secretory antibody phase, either the $C D 79 B \beta$ subunit or the $C D 79 A \alpha$ subunit is expressed. Thus, there is a shift to unimodal expression of the respective BCR subunits as the secretory phase is driven by the antigenic pressuromodulation effect, either positive or negative. The positive antigen pressuromodulator effect via B-plasma cell toll-like receptors (TLR) for example will increase B-cell pressure and maintain it in the supra-pressuromodulated gene expression range ( $>0.25$ esebssiwaago $T_{\mathrm{Q}}$ units) such as in the case of V3-23DJ-IGHM and V1-3DJ-IGHM for example [20]; while, the negative antigen pressuromodulator effect via cell membrane perturbation for example will decrease B-cell pressure and maintain it in the infra-pressuromodulated gene expression range ( $<0.25$ esebsiwaagoT $_{\mathrm{Q}}$ units) such as in the case of V5-51DJ-IGHM [20].

The complete cell membrane (CM) BCR with antibody Fab region-bound antigen does not positively pressuromodulate B-cells to any significant degree. This contrasts with mast cells, which mediate IgE 
hypersensitivity. Mast cell Fc gamma receptor-bound IgE pressuromodulates, that crosslinked by specific antigen also pressuromodulates, in synergism with $\mathrm{CM}$ receptor-bound mast cell degranulating peptide (MCD), an endocytic pressuromodulator.

Supra-pressuromodulated VDJ recombinase gene RAG2 with an esebssiwaago $T_{Q}$ of 0.306 and infra-pressuromodulated $R A G 1$ with an esebssiwaago $T_{Q}$ of 0.139 are bimodally expressed and mechanistically mutually exclusive

The VDJ recombinase genes, RAG2 (esebssiwaago $T_{\mathrm{Q}}$ : 0.306 ) and $R A G 1$ (esebssiwaago $T_{\mathrm{Q}}: 0.139$ ) are bimodally expressed (Fig. 1); this maximizes the efficiency of the Bcell VDJ gene recombination process as the enzymes are mechanistically mutually exclusive.

Only one VDJ recombinase, either RAG1 or RAG2, is required during any pressuromodulation period since the $\mathrm{D} \rightarrow \mathrm{J}$ (or $\mathrm{J} \rightarrow \mathrm{D}$ ) sub-phase of the $3^{\prime}-\mathrm{J}(7)(23)(9) \leftrightarrow$ (7)(12)(9) $\mathrm{D}(9)(12)(7) \leftrightarrow(9)(23)(7) \mathrm{V}-5^{\prime}$ process $[19,24]$ is as follows: (1) one recombinase grasps the $\mathrm{D}$ gene flanking heptamer bases i.e. RAG2 at an intracellular pressure of $0.31+/-$ esebssiwagoot $T_{\mathrm{Q}}$ units when the $\mathrm{D}$ gene locus is horizontal; (2) the intracellular pressure decreases and the strand breaks at the RAG2 still boundbase handle; (3) the other recombinase grasps the J gene flanking nonomer bases i.e. RAG1 at an intracellular pressure of $0.14+/-$ esebssiwaago $T_{\mathrm{Q}}$ units when the $\mathrm{J}$ gene locus is horizontal, and the strand breaks at the RAG1 still bound-base handle; and (4) the D gene joins the $J$ gene and the $\mathrm{D} \rightarrow J$ step is complete, and vice versa in case of $\mathrm{J} \rightarrow \mathrm{D}$.

Thus, an esebssiwaago $T_{\mathrm{Q}}$ match is not necessary in VDJ recombinase-dependent gene recombination [20], as the mechanism is as such.

Supra-to-infra-pressuromodulated CSR enzyme gene loci genes $A / C D A, A P O B E C 3 A /-B, A P O B E C 3 C /-D /-F /-G$ and $A P O B E C 3 H$ express over a wide range of esebssiwaago $T_{Q} S$, the range for iCSR, homologous recombination and CSR

The CSR enzyme gene loci include AICDA that expresses at 0.266 esebssiwaago $T_{\mathrm{Q}}$ units, $A P O B E C 3 A /-B$ at 0.216 esebssiwaago $T_{\mathrm{Q}}$ units, $A P O B E C 3 C /-D /-F /-G$ at 0.173 esebssiwaago $T_{\mathrm{Q}}$ units and $A P O B E C 3 H$ at 0.102 esebssiwaago $T_{\mathrm{Q}}$ units. $A P O B E C 3 H$ is not a significant contributor as it is expressed at 0.102 units, which is a transient B-cell pressure at the nadir. Thus, post$\mathrm{V}(\mathrm{D}) \mathrm{J}$ gene internal consensus sequence recognition (iCSR), homologous recombination (HR) and CSR is most efficiently achieved within the 0.281 to 0.158 esebsiwaago $T_{\mathrm{Q}}$ units pressure range, although they do take place at cell pressures as low as 0.13 units [20], for which the $A P O B E C 3 C /-D /-F /-G$ locus expressed enzyme concentrations are sufficient. The upper range for expression is 0.266 plus 0.015 and the lower range is 0.173 minus 0.015 units as the respective genes/gene loci are sufficiently horizontal within \pm

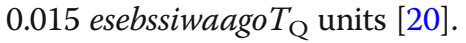

In comparison to $\mathrm{V}(\mathrm{D}) \mathrm{J}$ recombination [19], iCSR [25], homologous recombination [26] and CSR [19] require that both DNA strands be horizontal at the same intracellular pressure for simultaneous enzymatic activity at downstream and upstream AGC trinucleotide base-rich sequences at the same time $[27,28]$. Therefore, an esebssiwaago $T_{\mathrm{Q}}$ match is necessary for iCSR, homologous recombination and CSR [20].

There is always an initial internal CSR (iCSR) of the IGHM switch sequence region [25] that results in $V(D) J-I G H M$ [20]. There are four transcribeable $M I R$ genes at 3 separate gene loci within IGHM's upstream switch region, which render the IGHM switch sequence more stably horizontal than the other heavy chain loci gene switch sequences [20]. This is probably why IGHM internal CSRs early [25], while the switch regions of the downstream heavy chain genes, IGHG3, IGHG1, IGHA1, IGHG4, IGHE and IGHA2, preferentially CSR to VDJ6-remaining $M I R / M I R s-I G H M$ 's switch region after its internal CSR [20].

In the case of Allele 2 (IGHD), when there is no esebssiwaago $T_{\mathrm{Q}}$ match for homologous recombination and initial allelic exclusion, then there is delayed $\mathrm{iCSR}$ of the IGHM switch region on Allele 2 [20], which results in a $\operatorname{IgM}+\operatorname{IgM}+$ Mature naïve B-cell.

Trimodal expression of somatic hypermutation enzyme genes AICDA with an esebssiwaago $T_{Q}$ of $0.266, A P O B E C 3 A$ $B$ with an esebssiwaago $T_{Q}$ of 0.216 and $A P O B E C 3 C /-D /-F /$ $-G$ with an esebssiwaago $T_{Q}$ of 0.173 is consistent with maximum SHM for AGC trinucleotide base-rich antibody genes expressing at around the respective esebssiwaagot $T_{Q}$

The somatic hypermutation (SHM) enzyme gene AICDA is expressed frequently, between the maximum polarization and half-refractory periods at an intracellular pressure of 0.266 esebssiwaago $T_{\mathrm{Q}}$ units. While, the four SHM enzyme gene locus genes, $A P O B E C 3 C$, $A P O B E C 3 D, A P O B E C 3 F$ and $A P O B E C 3 G$ are expressed during the peri-nadir of the full refractory periods at an intracellular pressure of around 0.173 esebssiwaago $T_{\mathrm{Q}}$ units (Fig. 1).

Somatic hypermutation takes place during B-cell maturation via the classical pathway $[10,18,29]$. It appears to be related to the frequency and duration of CD4R+ T-cell dependent B-cell pressure responses to certain pressures: (1) $0.266 \pm 0.015$ (0.281 to 0.251 ) esebssiwaago $T_{\mathrm{Q}}$ units range in which V3-23DJ-IGHM 
and V3-23DJ-IGHG1 CSR [20]; (2) $0.216 \pm 0.015$ (0.231 to 0.201$)$ esebssiwaago $T_{\mathrm{Q}}$ units range in which $C D 38$ expresses at $0.212 \pm 0.015$ (0.227 to 0.197) units [30] and $C D 27$ at $0.194 \pm 0.015$ (0.209 to 0.179$)$ units [31]; and (3) $0.173 \pm 0.015$ (0.188 to 0.158$)$ esebssiwaago $T_{\mathrm{Q}}$ units range in which $C D 19$ expresses at $0.153 \pm 0.015$ (0.168 to 0.138) units [32] and the $I G H_{-}$genes sequentially CSR to a tertiary CSR in reference to V551DJ-IGHM [20].

Therefore, there should be maximum somatic hypermutation for CSR recombining and/or recombined immunoglobin heavy chain genes at around the respective SHM enzyme expression esebssiwaago $T_{\mathrm{Q}} \mathrm{S}$, which are also the intracellular pressures at which the heavy chain expressing genes are horizontal for maximum enzymatic AGC trinucleotide Cytidine base substitution with Uridine, DNA strand breakage, and replacement of phosphorylated Uridine with a phosphorylated Adenine nucleotide $[19,27,28]$.

Supra-pressuromodulated cell proliferation marker genes $P C N A$ with an esebssiwaago $T_{Q}$ of $0.283, M K I 67$ with an esebssiwaago $T_{Q}$ of 0.329 , and ESPL1 with an esebssiwaago $T_{Q}$ of 0.275 express unidirectionally

For productive progression to mitogenesis cell division, the sequential expression of proliferative phase transcription factor genes is necessary, which begin expressing in the intracellular pressure range between 0.245 and 0.260 esebssiwaago $T_{\mathrm{Q}}$ units [2]. The proliferation marker genes follow in expression, PCNA (esebssiwaago $T_{\mathrm{Q}}:$ 0.285) expresses just prior to mitoses during the DNA synthesis sub-phase, ENPP1 (esebssiwaago $T_{\mathrm{Q}}:$ 0.308) expresses in mitoses [33], MKI67 (esebssiwaago $T_{\mathrm{Q}}$ : 0.329) expresses early in mitoses and as early as prophase [34, 35], while ESPL1 (esebssiwaago $T_{\mathrm{Q}}$ : 0.275 ) expresses later in mitoses during anaphase [36].

The proliferative marker genes are expressed during Large pre-B cell division to Small pre-B-cells, during Immature B-cell division to Mature naïve B-cells as well as during Mature naïve B-cell division to Evolved mature (naïve) B-cells (Fig. 1).

The proliferation marker genes are uni-directionally expressed, PCNA $\rightarrow$ MKI67 $\rightarrow$ ESPL1 (Fig. 1), which in the case of ESPL1 implies that one or more limiting transcription factors must be expressed at an intracellular pressure greater than 0.275 esebssiwaago $T_{\mathrm{Q}}$ units rather than at an intracellular pressure lower than 0.275 units.

\section{Conclusions}

In this study, B-cell differentiation has been studied by esebssiwaago $T_{\mathrm{Q}}$-based pressuromodulation mapping. Pressuromodulation mapping has been performed by arranging B-cell stage marker genes pressurotopically by esebssiwaago $T_{Q}$ in descending and ascending order in reference to the three periods of $\mathrm{B}$-cell polarization and B-cell maturation stage.

The esebssiwaago $T_{\mathrm{Q}}$-based pressuromodulation map simulates the B-cell maturation process for the classical pathway (T-cell mediated pressuromodulation effect pathway) and applies to the parallel non-classical pathway ( $\mathrm{T}$-cell independent antigen-mediated pressuromodulation effect pathway).

Henceforth, the B-cell pressuromodulation map can be utilized as the template for the study of specific B-cell recombination events including bi-allelic $\mathrm{V}(\mathrm{D}) \mathrm{J}$ gene recombination, IGHM internal consensus recognition sequence (iCSR), IGHD homologous recombination or initial allelic exclusion, further consensus recognition sequence (CSR) isotype switchings and somatic hypermutation, as in Part II.

\section{Additional file}

Additional file 1: Table S1. Non-chromosome 14 gene location data with tropy pairing and isotropy type. Stem cell marker gene, CD34; transcription factor adapter gene, PRDM1 and B-cell polarization genes, PTPRC and CD40; B-cell cluster of differentiation receptor genes, CD19, MS4A1, CR2, CD27 and CD38; cluster of differentiation receptor B-cell antigen receptor complex-associated proteins, CD79A and CD79B; Third, VDJ recombinase genes, $R A G 2$ and $R A G 1$, and consensus sequence recognition (CSR)/somatic hypermutation enzyme genes, APOBEC3AVAPOBEC3B, A/CDA, $A P O B E C 3 C / A P O B E C 3 D / A P O B E C 3 F / A P O B E C 3 G$, and $A P O B E C 3 H$; and cell proliferation marker genes, PCNA, ENPP1, MKI67 and ESPL1. (PDF $843 \mathrm{~kb}$ )

\section{Abbreviations}

ACM: Anisotropy converted-to-mesotropy; ASEBS: Anisotropic sub-episode block sum(s); dppASEBS: Downstream part anisotropic sub-episode block sum; dppasebssiwa: Downstream part anisotropic sub-episode block sums split-integrated average; dppesebssiwaa: Average of the downstream part episodic sub-episode block sums split-integrated average-average; dpPMSEBS: Downstream part mesotropic sub-episode block sum; dppmsebssiwa: Downstream part mesotropic sub-episode block sums split-integrated weighted average; esebssiwaago $T_{Q}$ : Episodic sub-episode sums splitintegrated weighted average-averaged gene overexpression tropy quotient; MSEBS: Mesotropic sub-episode block sum(s); NC: Non-contributory; NCA: Non-contributory anisotropic sub-episode block; NCstl: Noncontributory single or multiple stabilizing isotropy points or reverse stabilizing isotropy point(s); $\operatorname{prpT}_{\mathrm{Q}}$ : Paired point tropy quotient; stlsotropy: Stabilizing isotropy; SEB: Sub-episode block(s); stMfA: Indirect reverse stlsotropy and/or stlsotropy for anisotropy; stMfM: Indirect reverse stlsotropy and/or stlsotropy for mesotropy; uppASEBS: Upstream part anisotropic sub-episode block sum; uppasebssiwa: Upstream part anisotropic sub-episode block sums split-integrated weighted average;

uppesebssiwaa: Upstream part episodic sub-episode block sums split-integrated weighted average-average; uppMSEBS: Upstream part mesotropic sub-episode block sum; uppmsebsziwa: Upstream part mesotropic sub-episode block sums split-integrated weighted average; TF ANT: Transcription factor antagonist; CSR: Consensus sequence recognition; HR: Homologous recombination; SHM: Somatic hypermutation

\section{Acknowledgements}

Not applicable

Funding

No funding was applied for this research. 


\section{Availability of data and materials}

The mined data utilized in this study is publicly available at the GeneCards database (https://www.genecards.org/) genomic neighborhood GeneLoc genome locator (https://genecards.weizmann.ac.il/) and the LNCipedia.org database (http://www.Incipedia.org/). All data analysed this study are included in the supplementary information files of this article.

\section{Authors' contributions}

HS conceptualized the research, developed the methodology, analyzed the data, and wrote the manuscript.

\section{Ethics approval and consent to participate}

Not applicable

\section{Consent for publication}

Not applicable

\section{Competing interests}

The author declares that he has no competing interests.

\section{Publisher's Note}

Springer Nature remains neutral with regard to jurisdictional claims in published maps and institutional affiliations.

\section{Received: 4 December 2017 Accepted: 26 January 2018}

Published online: 15 March 2018

\section{References}

1. Sarin H. Pressuromodulation at the cell membrane as the basis for small molecule hormone and peptide regulation of cellular and nuclear function. J Transl Med. 2015;13(372)

2. Sarin $\mathrm{H}$. Horizontal alignment of $5^{\prime}->3^{\prime}$ intergene distance segment tropy with respect to the gene as the conserved basis for DNA transcription. Future Sci OA. 2017;3(1):FSO1610.

3. Sarin H. Mechanism underlying pressuromodulation-mediated horizontal alignment of a gene for maximal transcription as predicted by the esebssiwaagoT, TBD(TBD):TBD. 2018 Submitted 30 Dec 2017.

4. Murphy K, Travers P, Walport M, Janeway C: Immunobiology. New York: Garland Science 8th ed xix 868; 2012

5. Banchereau J, Bazan F, Blanchard D, Briere F, Galizzi JP, van Kooten C, Liu YJ, Rousset F, Saeland S. The CD40 antigen and its ligand. Annu Rev Immunol. 1994;12:881-922.

6. Arpin C, Dechanet J, Van Kooten C, Merville P, Grouard G, Briere F, Banchereau J, Liu YJ. Generation of memory B cells and plasma cells in vitro. Science. 1995;268(5211):720-2.

7. Di Rosa F, Pabst R. The bone marrow: a nest for migratory memory T cells. Trends Immunol. 2005;26(7):360-6.

8. Duchez S, Rodrigues M, Bertrand F, Valitutti S. Reciprocal polarization of T and B cells at the immunological synapse. J Immunol. 2011;187(9):4571-80.

9. Takeda K, Kaisho T, Akira S. Toll-like receptors. Annu Rev Immunol. 2003;21(1):335-76

10. Budeus B, Schweigle de Reynoso S, Przekopowitz M, Hoffmann D, Seifert M, Kuppers R. Complexity of the human memory B-cell compartment is determined by the versatility of clonal diversification in germinal centers. Proc Natl Acad Sci U S A. 2015;112(38):E5281-9.

11. Mandal S, Lindgren AG, Srivastava AS, Clark AT, Banerjee U. Mitochondrial function controls proliferation and early differentiation potential of embryonic stem cells. Stem Cells. 2011:29(3):486-95.

12. Fear DJ, McCloskey N, O'Connor B, Felsenfeld G, Gould HJ. Transcription of Ig Germline genes in single human B cells and the role of cytokines in Isotype determination. J Immunol. 2004;173(7):4529.

13. Shapiro-Shelef M, Lin Kl, McHeyzer-Williams LJ, Liao J, McHeyzer-Williams MG Calame K. Blimp-1 is required for the formation of immunoglobulin secreting plasma cells and pre-plasma memory B cells. Immunity. 2003;19(4):607-20.

14. Jackson SM, Harp N, Patel D, Wulf J, Spaeth ED, Dike UK, James JA, Capra JD. Key developmental transitions in human germinal center B cells are revealed by differential CD45RB expression. Blood. 2009;113(17):3999-4007.

15. Taylor JJ, Pape KA, Jenkins MK. A germinal center-independent pathway generates unswitched memory $B$ cells early in the primary response. J Exp Med. 2012;209(3):597-606.
16. Raval FM, Mishra R, Garcea RL, Welsh RM, Szomolanyi-Tsuda E. Long-lasting T cell-independent lgG responses require MyD88-mediated pathways and are maintained by high levels of virus persistence. MBio. 2013;4(6):e00812-13.

17. Bortnick A, Chernova I, Quinn WJ 3rd, Mugnier M, Cancro MP, Allman D. Longlived bone marrow plasma cells are induced early in response to T cellindependent or T cell-dependent antigens. J Immunol. 2012;188(11):5389-96.

18. Bohannon C, Powers R, Satyabhama L, Cui A, Tipton C, Michaeli M, Skountzou I, Mittler RS, Kleinstein SH, Mehr R, et al. Long-lived antigen-induced IgM plasma cells demonstrate somatic mutations and contribute to long-term protection. Nat Commun. 2016;7:11826.

19. Dudley DD, Chaudhuri J, Bassing $\mathrm{CH}$, Alt FW. Mechanism and control of $V(D) J$ recombination versus class switch recombination: similarities and differences. Adv Immunol. 2005:86:43-112.

20. Sarin H. B-cell antibody class switchings are pressuromodulated events: Part II, gene recombination. Translational Medicine Communcations. In press.

21. Nair R, Ngangan AV, Kemp ML, McDevitt TC. Gene expression signatures of extracellular matrix and growth factors during embryonic stem cell differentiation. PLoS One. 2012;7(10):e42580.

22. Roccio M, Schmitter D, Knobloch M, Okawa Y, Sage D, Lutolf MP. Predicting stem cell fate changes by differential cell cycle progression patterns. Development. 2013;140(2):459-70.

23. Rolando L, Schneider WJ, Steinberg S, Low S, Stiles J, Gomez L, Gershon AA Brown AE. Effect of Varicella-zoster virus (VZV) fluorescent- antibody-tomembrane-antigen (FAMA) testing on sensitivity of determining VZV immunity in healthcare workers and on furlough days. Infect Control Hosp Epidemiol. 2015;31(9):972-4.

24. Nagawa F, Kodama M, Nishihara T, Ishiguro K, Sakano H. Footprint analysis of recombination signal sequences in the 12/23 synaptic complex of $V(D) J$ recombination. Mol Cell Biol. 2002;22(20):7217-25.

25. Dudley DD, Manis JP, Zarrin AA, Kaylor L, Tian M, Alt FW. Internal IgH class switch region deletions are position-independent and enhanced by AID expression. Proc Natl Acad Sci U S A. 2002;99(15):9984-9.

26. White MB, Word CJ, Humphries CG, Blattner FR, Tucker PW. Immunoglobulin D switching can occur through homologous recombination in human $B$ cells. Mol Cell Biol. 1990;10(7):3690-9.

27. Chelico L, Pham P, Goodman MF. Stochastic properties of processive cytidine DNA deaminases AID and APOBEC3G. Philos Trans R Soc Lond Ser B Biol Sci. 2009;364(1517):583-93.

28. Muramatsu M, Kinoshita K, Fagarasan S, Yamada S, Shinkai Y, Honjo T. Class switch recombination and hypermutation require activation-induced cytidine deaminase (AID), a potential RNA editing enzyme. Cell. 2000;102(5):553-63.

29. Meffre E, Catalan N, Seltz F, Fischer A, Nussenzweig MC, Durandy A. Somatic Hypermutation shapes the antibody repertoire of memory $B$ cells in humans. J Exp Med. 2001:194(3):375-8.

30. Wilson PC, de Bouteiller O, Liu YJ, Potter K, Banchereau J, Capra JD, Pascual $\checkmark$. Somatic hypermutation introduces insertions and deletions into immunoglobulin V genes. J Exp Med. 1998;187(1):59-70.

31. Klein U, Rajewsky K, Küppers R. Human immunoglobulin (lg)M(+)lgD(+) peripheral blood B cells expressing the CD27 cell surface antigen carry somatically mutated variable region genes: CD27 as a general marker for somatically mutated (memory) B cells. J Exp Med. 1998;188(9):1679-89.

32. Fecteau JF, Cote G, Neron S. A new memory CD27-lgG+ B cell population in peripheral blood expressing $\mathrm{VH}$ genes with low frequency of somatic mutation. J Immunol. 2006;177(6):3728-36

33. Yoon J, Wang $H$, Kim YC, Yoshimoto $M$, Abbasi $S$, Morse lii HC. Plasma cell alloantigen ENPP1 is expressed by a subset of human B cells with potential regulatory functions. Immunol Cell Biol. 2016:94(8):719-28.

34. Kraus H, Kaiser S, Aumann K, Bonelt P, Salzer U, Vestweber D, Erlacher M, Kunze $M$, Burger $M$, Pieper $K$, et al. A feeder-free differentiation system identifies autonomously proliferating B cell precursors in human bone marrow. J Immunol. 2014;192(3):1044-54.

35. Sobecki M, Mrouj K, Camasses A, Parisis N, Nicolas E, Llères D, Gerbe F, Prieto S, Krasinska L, David A, et al. The cell proliferation antigen Ki-67 organises heterochromatin. elife. 2016;5:e13722.

36. Ciosk R, Zachariae W, Michaelis C, Shevchenko A, Mann M, Nasmyth K. An ESP1/PDS1 complex regulates loss of sister Chromatid cohesion at the metaphase to anaphase transition in yeast. Cell. 1998;93(6):1067-76. 